\title{
Czech Republic: Technical Note on Stress Testing the Banking Sector
}

This paper was prepared based on the information available at the time it was completed in July 2012. The views expressed in this document are those of the staff team and do not necessarily reflect the views of the government of Czech Republic or the Executive Board of the IMF.

The policy of publication of staff reports and other documents by the IMF allows for the deletion of market-sensitive information.

Copies of this report are available to the public from

International Monetary Fund • Publication Services

700 19th Street, N.W. • Washington, D.C. 20431

Telephone: (202) 623-7430 • Telefax: (202) 623-7201

E-mail: publications@imf.org • Internet: http://www.imf.org

\section{International Monetary Fund Washington, D.C.}


FINANCIAL SECTOR ASSESSMENT PROGRAM UPDATE CZECH RePUBLiC

Stress Testing the BAnKing SECtor

TECHNICAL NOTE

JULY 2012

INTERNATIONAL MONETARY FUND

MONETARY AND FINANCIAL SYSTEMS DEPARTMENT 


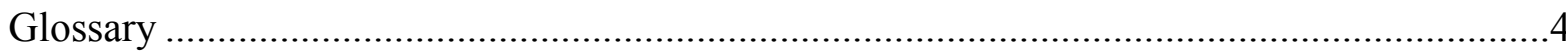

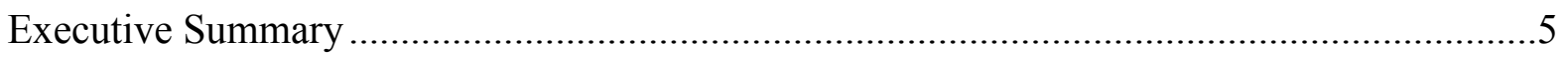

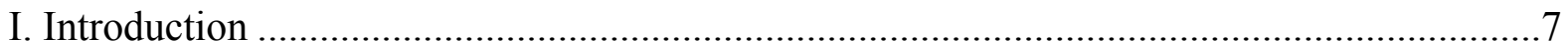

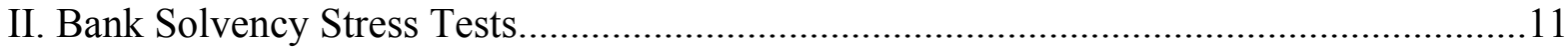

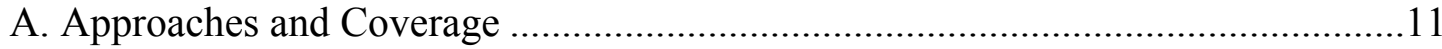

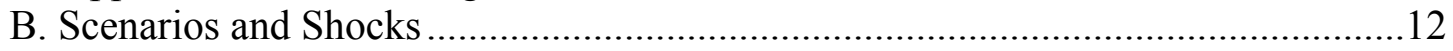

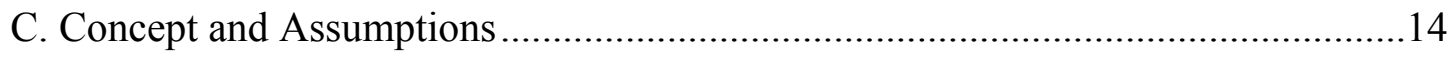

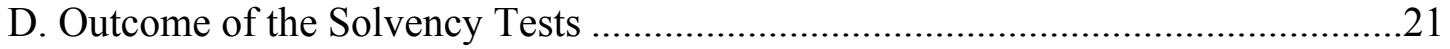

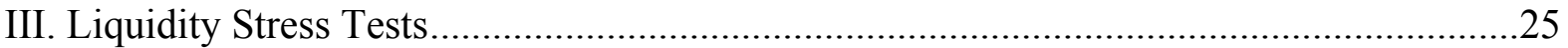

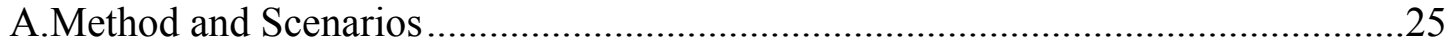

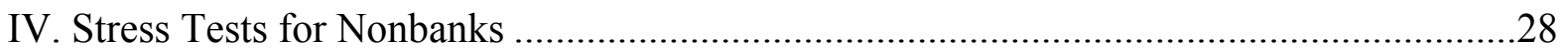

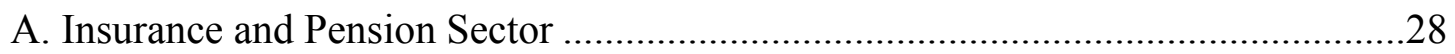

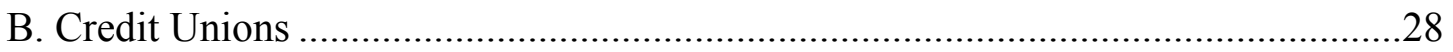

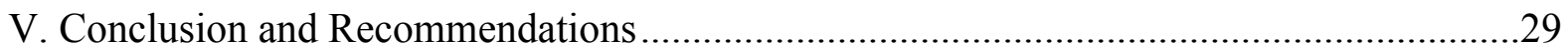

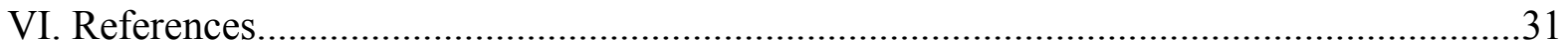

Tables

1. Comparison of Different Solvency Stress Test Methods....................................................12

2. Overview of the Modeling of Key Solvency Parameters ....................................................15

3. Overview of the Basel III Minimum Capital Requirements..................................................2

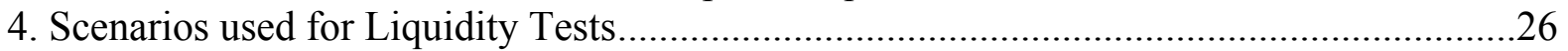

Figures

1. Financial Soundness Indicators for the Czech Banking System..........................................8

2. Overview of the FSAP Bank Stress Testing Framework .................................................10

3. GDP Trajectories Under Different Scenarios ................................................................14

4. Potential Impact of Pillar 2 Capital Charges for Name Concentration................................17

5. Outcome of Solvency Stress Tests for the Czech Banking System.....................................22

6. Distribution of the Outcome of Solvency Stress Tests .......................................................23

7. Outcome of Liquidity Stress Tests for the Czech Banking System...................................22

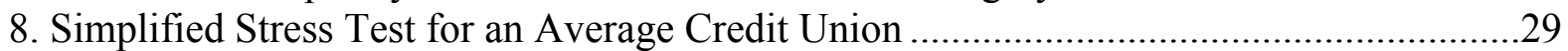

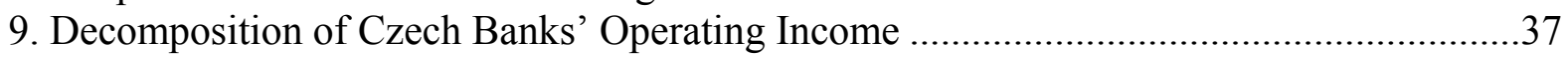

10. Schematic Overview for the Calibration of Funding Costs ................................................4 


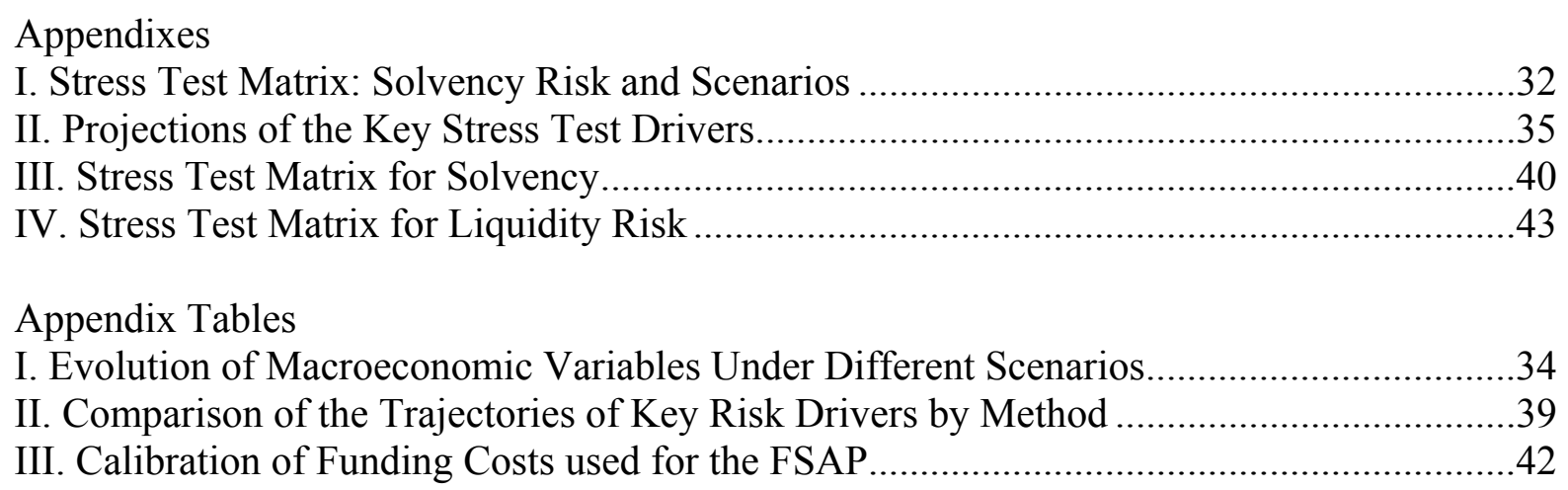




\section{GLOSSARY}

$\begin{array}{ll}\text { BCBS } & \text { Basel Committee on Banking Supervision } \\ \text { BU } & \text { Bottom-up (stress test) } \\ \text { CEE } & \text { Central and Eastern Europe } \\ \text { CNB } & \text { Czech National Bank } \\ \text { CZK } & \text { Czech koruna } \\ \text { DD } & \text { Double dip (scenario) } \\ \text { EAD } & \text { Exposure at default } \\ \text { FSAP } & \text { Financial Sector Assessment Program } \\ \text { FSSA } & \text { Financial Sector Stability Assessment } \\ \text { FX } & \text { Foreign exchange (rate) } \\ \text { GIIPS } & \text { Greece, Ireland, Italy, Portugal, Spain } \\ \text { IMF } & \text { International Monetary Fund } \\ \text { IRB } & \text { (Basel II) Internal Ratings-Based (approach) } \\ \text { LCR } & \text { Liquidity coverage ratio } \\ \text { LGD } & \text { Loss given default } \\ \text { NSFR } & \text { Net stable funding ratio } \\ \text { PD } & \text { Probability of default } \\ \text { PIT } & \text { Point-in-time (credit risk parameters) } \\ \text { PPT } & \text { Percentage point } \\ \text { ROC } & \text { Regulatory capital } \\ \text { ROE } & \text { Return on equity } \\ \text { RWA } & \text { Risk-weighted assets } \\ \text { StA } & \text { (Basel II) Standardized Approach } \\ \text { TD } & \text { Top-down (stress test) } \\ \text { TD CNB } & \text { Top-down test run by the CNB } \\ \text { TD IMF } & \text { Top-down test run by the IMF mission } \\ \text { WEO } & \text { World Economic Outlook } \\ & \end{array}$




\section{EXECUTIVE SUMMARY}

This note summarizes the stress tests undertaken for the Czech banking system as part of the Financial Sector Assessment Program (FSAP) Update. The tests were tailored to capture the specificities of the Czech banking system, characterized by a high share of foreign-owned banks. It also addressed current market developments and medium-term structural trends. The stress tests were undertaken in close cooperation with the Czech National Bank (CNB), using supervisory data, based on bottom-up tests (BU), and top-down tests (TD) run by the CNB (TD CNB) and the IMF mission (TD IMF).

All banks were assessed against solvency, liquidity, and contagion risks. ${ }^{1}$ Solvency tests for the Czech banking system assessed potential vulnerabilities under three adverse macroeconomic scenarios as well as baseline conditions. The tests considered a variety of measures of soundness, and took into account funding costs, sovereign risk, upcoming changes in the regulatory rules, and behavioral changes of banks in terms of profit retention and credit growth. The liquidity tests simulated banks' resilience against a sudden withdrawal of funding sources. Banks' maturity mismatch was assessed in follow-up analysis. Contagion risk was analyzed by simulating a partial loss of exposure to parents.

The Czech banking system faces two potential challenges: the impact from a severe macroeconomic downturn and weaknesses at the parent level. The system could be directly affected by the sovereign debt crisis (through the parent banks) or indirectly (through adverse macroeconomic growth scenario in their main trade partner economies), and the two channels are likely to occur simultaneously.

The solvency tests revealed that the Czech banking system is robust even against substantial shocks on a standalone basis, but that contagion risk from parents could render the system slightly undercapitalized. Measured against current and future supervisory standards (i.e., Basel II/III), Czech banks are, with few exceptions, sufficiently capitalized to withstand substantial levels of stress, and are shielded against their main risk, credit losses, thanks to their favorable income position, providing banks with a considerable first line of defense. In addition, Czech banks' direct exposure to the riskiest sovereign debt exposures in the Euro Area and outside the country more generally is quite limited, except for sizeable exposures to their parents, which are themselves more exposed to sovereign risks.

The liquidity stress tests found that the vast majority of banks are able to cope with large liquidity shocks, and will also meet Basel III standards. The Czech banks are

\footnotetext{
${ }^{1}$ The BU test covered the nine largest banks (about 80 percent of the assets); while the TD tests covered 22 banks. The TD tests thereby covered all banks, except for a newly established, small bank and the branches of foreign banks.
} 
funded mainly by local deposits, which ensures ample liquidity and makes them in a position to transfer part of their liquidity to their parents, subject to a regulatory limit.

Structural changes could reduce banks' profitability, and could amplify stress conditions in the medium/long term. Profitability could be reduced due to higher competition (a) as a result of fiercer competition for stable funding sources, and/or (b) the entry of new players due to the favorable risk-return ratios enjoyed by the Czech banks in international terms. In terms of financial stability, in addition to a potential reduction in lending margins over time (reducing banks' first defense line against losses and their capacity to build buffers), banks could attempt to counterbalance such a trend by lower lending standards. Structural tendencies should be taken into account in future stress tests, especially if the forecast horizon is extended beyond two to three years, which could inform macroprudential policies.

The resilience of the nonbank financial sector is mixed, but the impact is unlikely to be systemic. The resilience of the credit union sector has been assessed based on simplified stress tests, indicating that even slightly less favorable conditions as under the baseline could be challenging for about half of the credit unions. For the insurance sector, stress tests conducted by the CNB indicate substantial resilience of the system, also thanks to their high profitability. The latter is supported by separate analysis that reveal that the system is well capitalized in economic terms (i.e., under Solvency II). Future stress tests for the insurance and pension sectors should focus on longer-term vulnerabilities such as the potential impact of persistent low interest rates, assessing interest rate risk on both sides of the balance sheet, and be refined further on the liability side. 


\section{INTRODUCTION}

1. The Czech financial system proved resilient to the effects of the global financial crisis, but the uncertainty of the macroeconomic outlook in Europe could be a challenge going forward. Although subject to weakened macroeconomic conditions since the onset of the financial crisis, reflected in slightly increasing credit loss levels, Czech banks' capitalization remained high owing mainly to lower credit growth (Figure 1). During the last three years, banks further strengthened capitalization levels, with total capitalization increasing to 15.9 percent and 14.7 percent in terms of Tier 1 capitalization, by June 2011 . Hence, the Czech banking sector was one of the few in Central and Eastern Europe (CEE) which, so far, did not require public support. At the same time, banks' liquidity positions remain very favorable, with a loan-to-deposit ratio of around 70 percent.

2. The financial sector is dominated by a few large banks. Banks account for 84 percent of the financial sector assets, insurance companies and pension funds 13 percent, and investment funds for about 3 percent.

3. The banking system is concentrated, foreign-owned, and relatively small relative to the size of the economy. The assets of the financial system were around CZK 5 trillion (or 133 percent of GDP) as of end-2010. The ratio of credit to GDP is around 57 percent, which is about a third of the European Union-15 average. The 5 largest banks control more than 70 percent of total bank assets, and the 3 largest ones about 60 percent. Likewise, more than 70 percent of the system is directly foreign-owned (taking into account indirect ownership, foreign entities control more than 90 percent of the banking sector). The banking system's assets grew rapidly from 2000 to 2008, especially household loans, but balance sheet growth had almost stopped in 2009 as a result of the crisis, and the subsequent growth has been very moderate (Figure 1).

4. Banks enjoy favorable income levels and conservative business models. Income (in terms of Return on Equity (ROE)/Return on Capital (ROC)) has been very favorable since 2002, mainly due to lower levels of losses (Figure 1). Unlike in other CEE countries, Czech banks benefit from ample deposits and low levels of dollarization on both sides of the balance sheet.

5. Banks' exposure to peripheral Europe is limited. As outlined in a recent stress test carried out by the $\mathrm{CNB},{ }^{2}$ banks could absorb a 100 percent loss of their exposure to the GIIPS $^{3}$ countries (which is at about USD 1 billion), including to the corporate and bank sector as well as other counterparts other than sovereign.

\footnotetext{
${ }^{2}$ CNB, Czech Banking Sector Stress Tests, August 2011.

${ }^{3}$ GIIPS stands for Greece, Ireland, Italy, Portugal, and Spain.
} 
Figure 1. Czech Republic: Financial Soundness Indicators for the Czech Banking System

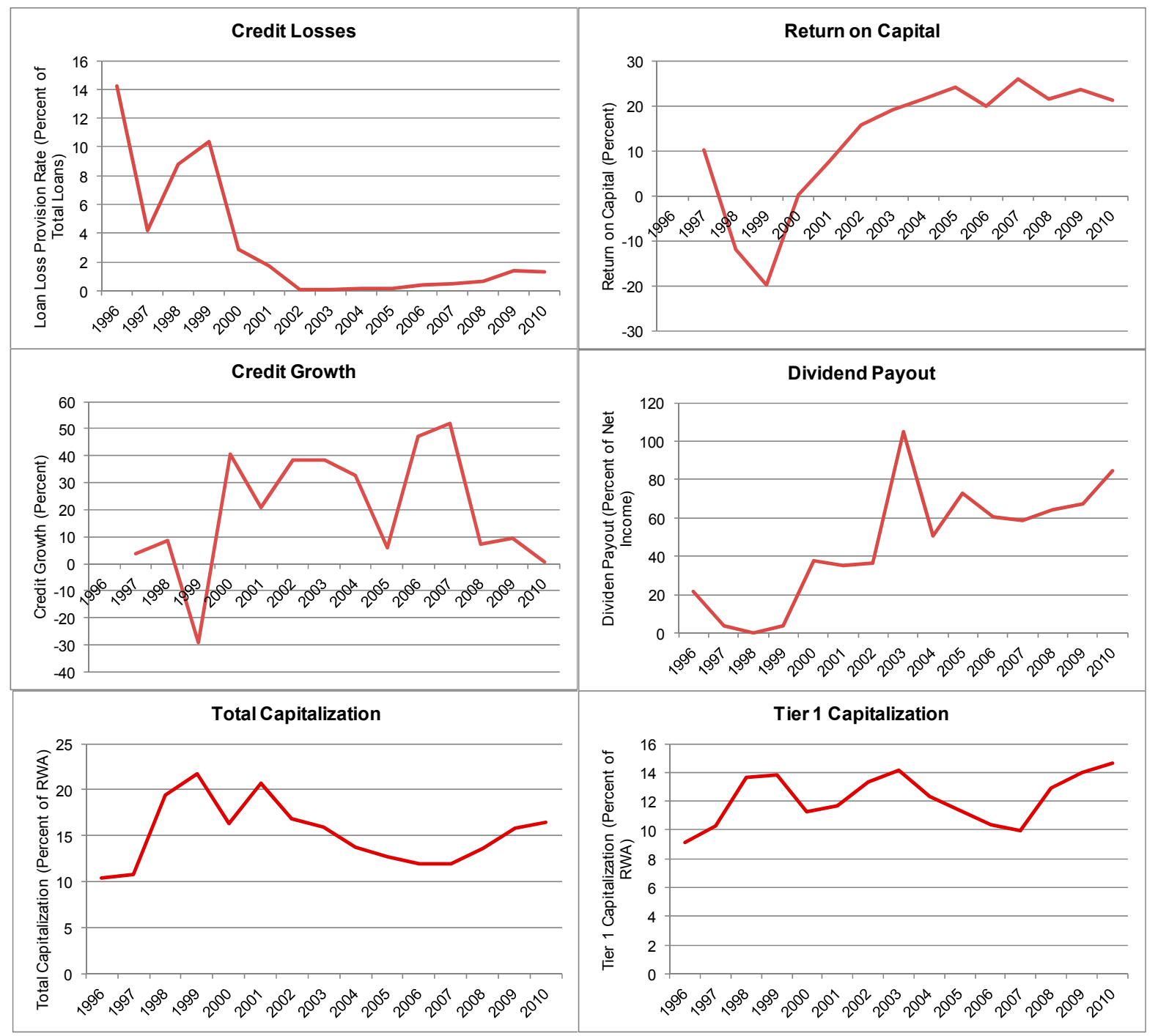

Source: IMF staff estimates based on Bankscope data. ${ }^{4}$

Note: Graph shows weighted average (weighted by bank assets)

\section{The performance of nonbank financial institutions has been mixed. Insurance} companies are profitable and well capitalized, including under risk-based solvency rules (Solvency II). Pension funds were more vulnerable, but have recently stabilized. The performance of the small but fast-growing credit union sector is weak, with a high share of

\footnotetext{
${ }^{4}$ The figures are broadly in line with CNB supervisory data. Possible discrepancies could arise due to different data coverage of Bankscope and supervisory data, for example. Please note that the number of observations in the early years is low and therefore provides only general tendencies.
} 
nonperforming loans and a relatively low loan loss provisioning ratios (see the pertinent technical note).

7. Going forward, macrofinancial conditions are highly uncertain. The macrofinancial environment is characterized by uncertain growth prospects in Europe on the one hand and weaknesses in the large European banks (outside the Czech Republic) on the other, as recently documented by the European Banking Authority (EBA). ${ }^{5}$ Under these circumstances, caution is also warranted for the Czech authorities, given the close links to parent banks and potential macroeconomic (inward) spillover effects.

8. The stress tests focused on tail risks and systemic effects. The aim was to gain a comprehensive view on potential short and medium-term vulnerabilities in the system, rather than to estimate recapitalization needs of individual banks. Thus, the focus differed from that regulatory stress tests, such as the European stress tests coordinated by the EBA. ${ }^{6}$ Unlike the latter exercises, the analysis explicitly included liquidity and contagion risks.

9. The stress tests covered a variety of solvency risks (including credit, market, funding, concentration, and sovereign debt risks), liquidity risks, and contagion risks (Figure 2). Given the high share of foreign-owned banks, one of the highest one in Europe, assessing potential in-ward spillover effects through parent banks was judged important, especially in current circumstances.

10. The design of the scenarios, shocks, assumptions, and methodologies was undertaken in close cooperation between the Czech authorities and the mission. The tests included stress test frameworks developed by the CNB (TD CNB), at the Fund (TD IMF), and by banks (BU), with the aim to assess risks from different and complementary perspectives.

11. The solvency tests focused on the behavior of the banking system under three adverse macroeconomic scenarios, and projected up to five years: (a) a moderate "double dip" (DD) recession; (b) a severe "DD" recession; and (c) a prolonged period of slow growth. These scenarios correspond to the main risk identified for the economy in general and the financial system in particular (Risk Assessment Matrix, Appendix I), and reflect the uncertainties going forward. The results under these scenarios were benchmarked against those obtained under a baseline scenario using August 2011 World Economic Outlook (WEO) projections.

\footnotetext{
${ }^{5}$ Press release by the EBA on the recapitalization needs of European banks as of December 8 . http://www.eba.europa.eu/News--Communications/Year/2011/The-EBA-publishes-Recommendation-and-finalresults.aspx.

${ }^{6}$ Unlike recent European and U.S. stress tests, the tests also did not focus on computing capitalization needs for specific banks.
} 


\section{The solvency tests were based on balance sheet approaches, and covered the} entire banking system. ${ }^{7}$ Dynamic effects were captured through the increase of funding costs conditional on capitalization, using evidence observed during the crisis. Contagion risks were captured by a partial loss of exposure to parent banks under the DD stress scenarios. Interbank exposures are limited, so explicit tests to simulate potential interbank contagion channels were included only in the CNB TD tests as the module to test the interbank contagion risk is an integral part of the CNB TD stress testing framework (Appendix III).

\section{The liquidity tests focused on funding shocks, accounting for the} counterbalancing capabilities of banks. The analysis also shed some light on risks arising from maturity mismatch and upcoming Basel III changes. The BU stress tests were used as a cross-check against TD results based on supervisory data. Two scenarios were simulated, a moderate one and a severe one; the latter simulating more adverse conditions than the ones faced by banks after the Lehman collapse. Further details are given in Appendix IV.

Figure 2. Czech Republic: Overview of the FSAP Bank Stress Testing Framework

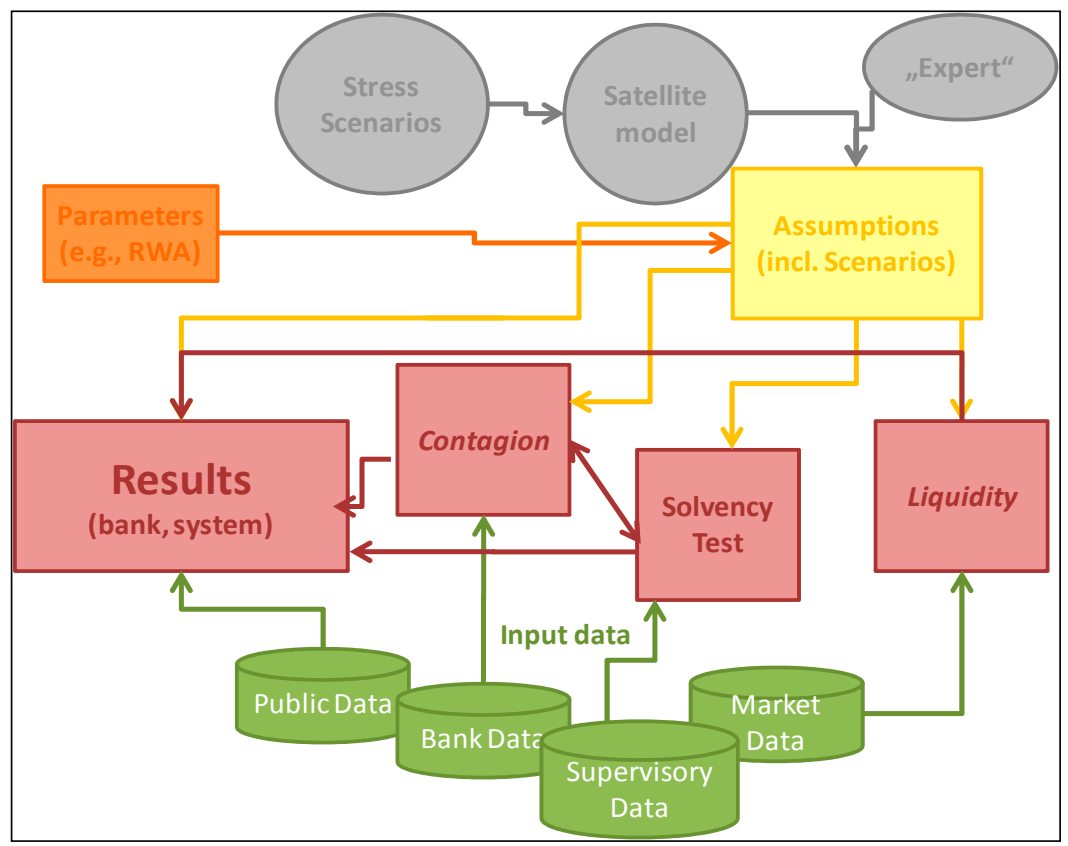

Source: IMF staff

\section{A simplified stress test has been undertaken for the credit union sector. No} separate stress for the insurance and pension sectors test were run as part of the FSAP. The stress test carried out in May 2011 by the CNB shows that the insurance sector appears resilient against shocks, while this is less the case for the pension sector.

\footnotetext{
${ }^{7}$ The BU tests covered the nine largest banks.
} 


\section{BAnK Solvency STRESS Tests}

\section{A. Approaches and Coverage}

15. The solvency tests covered a period of three to five years and assessed the impact of different stress levels based on three approaches (Table 1). The aim was to gain a comprehensive view on the vulnerabilities in the system and differences across different groups of banks (large, medium-sized, and small banks; building societies). The analysis for the outer years of the projection horizon (until 2016) were meant to capture the full impact of stress over time, including the recovery process, the impact of period of quasi-zero growth and potential structural tendencies rather than specific point estimates, owing to the uncertainty that comes with longer time horizons.

16. The FSAP tests involved various stakeholders (CNB's monetary policy, financial stability, financial supervision, and financial regulation departments as well as the IMF mission) and used most recent supervisory data as well as bank data. In addition to that, the FSAP mission has run supplementary tests to assess vulnerabilities for (and within) the largest banking groups based on publicly available data to complement the stress test results, which were also meant to draw broader conclusions. ${ }^{8}$

17. The objective of the BU tests was to make use of the most granular data (i.e., bank data), and the experience of banks, and to shed light on banks' assumptions and/or strategic decisions. In addition to producing actual results, the BU tests were used as a robustness test for the TD tests and to assess banks' risk management framework and capabilities. The exercise proved highly relevant in the overall context, and extended previous BU tests run since 2009 to market and income risk, and the projection horizon from 1 to 2.5 years. ${ }^{9}$

18. The TD tests covered all $22^{10}$ locally registered banks, while the BU test was undertaken by the 9 largest banks, accounting for about 80 percent of the total assets. Banks were grouped into four subsets: (a) large banks; (b) medium-sized banks; (c) small banks; and (d) building societies. Accordingly, it was accounted for data confidentiality issues as well as for similarity in business models, respectively.

19. The solvency tests covered the next $2 \frac{1}{2}$ years for the BU tests, 3 years for the TD CNB tests and 5 years for the TD IMF tests. The differences in time horizon reflected

\footnotetext{
${ }^{8}$ Due to their limitation to the largest banks within a group context, the numerical results of the tests were not revealed.

${ }^{9}$ Banks used considerable efforts to run the tests in terms of making resources available.

${ }^{10}$ One newly established bank was omitted due to a lack of data.
} 
technical characteristics of the frameworks on the one hand and the frequency of the data on the other (Table 1).

Table 1. Czech Republic: Comparison of Different Solvency Stress Test Methods

\begin{tabular}{l|c|c|c|c}
\hline Type & Forecast period & Frequency & Scenarios & $\begin{array}{c}\text { Percent of } \\
\text { Banking system }\end{array}$ \\
\hline Bottom Up & Q3 2011- Q4 2013 & Quarterly & $\begin{array}{c}\text { Baseline, Moderate } \\
\text { and Severe Double } \\
\text { Dip (DD) }\end{array}$ & 80 \\
\hline Top Down (CNB) & Q3 2011- Q2 2014 & Quarterly & $\begin{array}{c}\text { Baseline, Moderate } \\
\text { and Severe DD }\end{array}$ & 100 \\
\hline $\begin{array}{l}\text { Top Down (IMF } \\
\text { framework) }\end{array}$ & Q3 2011- Q2 2016 & Annual & $\begin{array}{c}\text { Baseline, Moderate } \\
\text { and Severe DD, Slow } \\
\text { Growth; Proxy of } \\
\text { Basel III impact in all } \\
\text { cases }\end{array}$ & 100 \\
\hline
\end{tabular}

Source: IMF staff

\section{B. Scenarios and Shocks}

20. The tests simulated the impact of three different macroeconomic shock scenarios, as well as baseline conditions on Czech banks (see Appendix I):

- Baseline: The IMF WEO baseline forecast as of August 2011 was used to define baseline conditions. ${ }^{11}$ This baseline scenario assumed a slight deceleration of economic activity in 2012 and a bounce back to higher growth in 2013. An update of the outlook during the time of the mission in early December 2011 indicated some worsening of the outlook, but was not used for the tests.

- Moderate DD: simulated a domestic downturn scenario, resulting from direct and indirect contagion effects of shocks hitting major trading partners.

- Severe DD: simulated a global recession, triggered by the sovereign debt crisis in Europe, and amplified by fiscal concerns in other major economies, slow growth in the U.S., and a potential slowdown of growth in emerging market economies.

- Slow(ed) Growth: The rationale for slow(ed) growth is that stress could result in a period of near zero growth in Europe, mimicking to some extent past Japan-like "lost

\footnotetext{
${ }^{11}$ The IMF baseline forecast differed to some degree from the CNB forecast, but ensures consistency with assumptions used in other FSAPs.
} 
decade" conditions. ${ }^{12}$ The scenario was meant to simulate unfavorable growth conditions, triggered by weak external demand, and muddling-through like policy strategies.

\section{In terms of GDP trajectories (Figure 3), the severe DD scenario is roughly as} adverse as the most severe scenario run by the CNB over the past years. ${ }^{13}$ The severity of the scenario reflects current uncertainties in the market and is meant to assess the ultimate risk bearing capacity of the Czech banking system in case of major European (and worldwide) recession. In historical terms using international evidence, the likelihood of the scenarios (in terms of their GDP trajectories) is 15-20 percent for the moderate double dip, 1-2 percent for the severe double dip, and 5 percent for the slow growth scenario. ${ }^{14} \mathrm{~A}$ more detailed description of the (a) storyline underlying the stress scenarios and (b) the evolution of the key macroeconomic variables is provided in Appendix I.

\footnotetext{
${ }^{12}$ However, unlike the macro experience of Japan, this alternative scenario does not assume deflation, see Appendix I, Table 5.

${ }^{13}$ The scenario is more severe than the scenarios used in recent EBA European stress tests. In historical terms, the drop in growth was equal to 2.5 standard deviations (in terms of two year GDP growth, which has been used as a benchmark in the European stress tests), compared to 1.5 to 2 standard deviations in other recent European FSAPs.

${ }^{14}$ The numbers were inferred from the historical distribution of GDP growth rates in advanced and emerging economies. A scenario corresponding to the $2^{\text {nd }}$ percentile would correspond to a scenario with a likelihood of two percent in historical terms.
} 
Figure 3. Czech Republic: GDP Trajectories under Different Scenarios

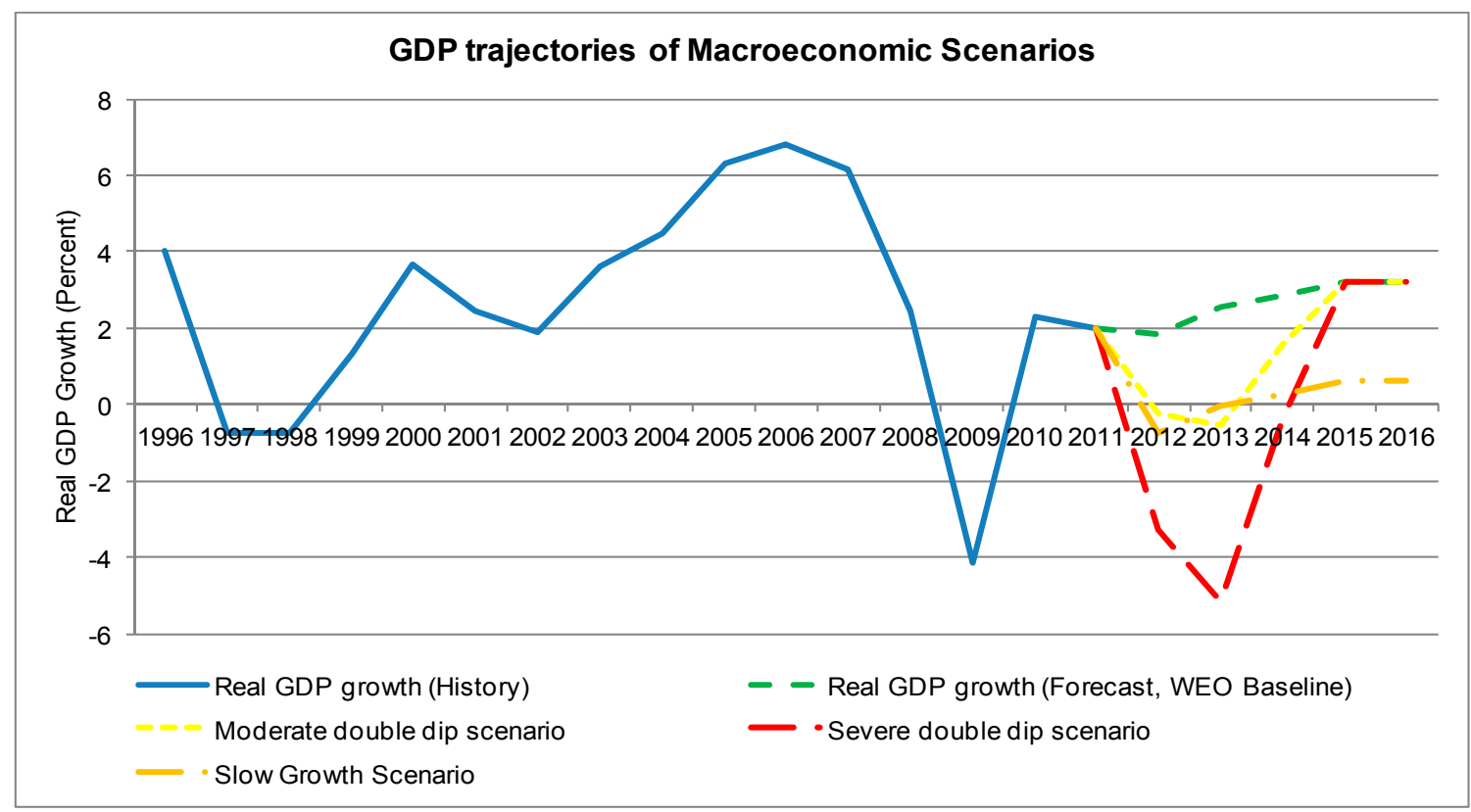

Source: IMF staff

\section{Concept and Assumptions}

22. The macroeconomic scenarios were linked to the developments of financial risks for banks through satellite models (Table 2). The link to macroeconomic conditions was established for credit losses, income and credit growth, and indirectly for Risk-weighted Assets (RWAs). For the large banks, a risk-based solvency measure was used (i.e., based on the internal Ratings-based (IRB) approach), while smaller banks were assessed based on the Basel II Standardized Approach (StA) (Appendix II and III). 


\section{Table 2. Czech Republic: Overview of the Modeling of Key Solvency Parameters}

\begin{tabular}{l|l}
\hline Parameter & Modeling \\
\hline $\begin{array}{l}\text { Predit Losses } \\
\text { LGD }\end{array}$ & $\begin{array}{l}\text { Use of Point-in-time parameters, based on: } \\
\text { Satellite model (BU, TD CN, TD IMF) } \\
\text { Satellite model, combined with expert judgment (BU, TD CNB), empirical PD-LGD link } \\
\text { (TD IMF) }\end{array}$ \\
\hline $\begin{array}{l}\text { EAD/Credit } \\
\text { Growth }\end{array}$ & Satellite model (TD CNB; TD IMF) \\
\hline Income & Satellite model, combined with expert judgment (BU, TD CNB model, TD IMF) \\
\hline $\begin{array}{l}\text { Funding Costs } \\
\text { part of income) }\end{array}$ & $\begin{array}{l}\text { Expert judgment (BU, TD CNB model), econometric approach based on crisis experience } \\
\text { in other countries (TD IMF) }\end{array}$ \\
\hline $\begin{array}{l}\text { Sovereign debt } \\
\text { haircuts }\end{array}$ & Inferred from market data \& expert judgment (same parameters for all approaches) \\
\hline $\begin{array}{l}\text { Profit retention } \\
\text { rate }\end{array}$ & $\begin{array}{l}\text { Expert judgment (CNB); conditional on severity of scenario and capital buffer, using } \\
\text { empirical evidence (IMF) }\end{array}$ \\
\hline Tax rate & Based on evidence (20 percent, all approaches) \\
\hline Basel III effects & $\begin{array}{l}\text { Phase-out of capital eligibility (TD IMF, based on expert judgment, oriented on QIS } \\
\text { results) }\end{array}$ \\
\hline
\end{tabular}

Source: IMF staff

23. Close attention was paid to specific risk factors: (a) peripheral sovereign debt risk; (b) funding risks; and (c) upcoming regulatory reforms (Table 2). Peripheral debt was stressed by applying haircuts to all GIIPS exposure; that is, including nonsovereign assets. ${ }^{16}$ Funding costs could increase due to fiercer competition and through inward contagion, but are unlikely to be as intense as in neighboring countries, reflecting banks' favorable funding policies. The upcoming changes in the context of Basel III, namely changes of hurdle rates, higher risk weights, and the phase-out of capital eligibility, were also taken into account, but focused on the latter issue given that the other aspects have a very limited impact.

\section{Due to the comparatively long period covered by the IMF framework, some} behavioral adjustment by banks was modeled (Table 2, see also below). The framework assumed that banks with low capital buffers (i.e., capital buffers less 2.5 percentage points (ppts) above the regulatory minimum of 8 percent) would retain all profits while banks would pay out a portion similar to the long-term average otherwise ( 50 percent $).{ }^{17}$ The credit growth

\footnotetext{
${ }^{15}$ Based on Schmieder, Puhr and Hasan (2011).

${ }^{16}$ Rather than simulating default events per se, the tests sought to assess potential losses incurred by banks, accounting for different stress levels conditional on the severity of the scenario, using recent FSAP experience based on market data, and some degree of expert judgment. Funding risks arise from a potential intensification of competition by banks for deposits (triggered by small banks and the credit union sector), and/or could be imported by unfavorable cross-border conditions (e.g., contagion from parents).

${ }^{17}$ The simulation of the dividend payout conditional on capital buffers is broadly consistent with the maximum pay-out rules foreseen under Basel III and close to average historical levels (60 percent).
} 
path established by the satellite models simulated some deleveraging in case of the severe DD scenario, in line with evidence, and to account for the fact that especially weak banks could do so to cope with stress. Sensitivity analyses were run to assess how the system would cope for different levels of credit growth and dividend payout, respectively, both under baseline and stress condition.

\section{Data used as a starting point for stress tests}

25. The data used as a starting point for the tests were scrutinized. Past experience has shown that the adequacy of the starting level of key stress tests parameters is crucial for meaningful multi-period tests. Income levels were particularly sensitive for banks with trading activities, which is not relevant in the Czech case, though. Capitalization levels could be affected by under-provisioning (resulting in overestimation of buffers), but as the larger banks are under IRB rules this is accounted for through a deduction from capital. It has also been found that IRB credit risk parameters (probabilities of default (PDs), loss given defaults (LGDs)) vary somehow across banks. It appeared that those differences are a consequence of different levels of risk appetite and business models, respectively, but should be monitored on an ongoing basis. ${ }^{18}$ For the non-IRB banks, average IRB credit risk parameters for the system have been applied, creating some uncertainty with respect to the reliability of the outcome (in both directions), but which is unlikely to have systemic implications as the non-IRB banks are mainly small banks. ${ }^{19}$

\section{Name concentration risk could be translated into (Pillar 2) capital needs and} used as an adjusted starting point. The IMF framework used for the FSAP includes a method to translate name concentration risk into additional capital requirements. The framework was applied to the Czech banks based on the name (i.e., credit) concentration of the 15 largest nonbank credit exposures on a borrower level. It was found that name concentration is relevant predominantly for the publicly-owned banks (with a substantial impact on the group of medium-sized banks) and some of the medium-sized and small(er) banks and that it would result in a reduction of capitalization by 1.1 ppts on the system level (from 16 percent to 14.9 percent) as of end June 2011 (Figure 4). To allow for better comparison of the tests, name concentration has not been included in the scenario analysis, but would slightly worsen the outcome of the tests.

\footnotetext{
18 The mission notes that such discussions have been carried out in the past, but recommends ongoing discussions on this vital subject to arrive at meaningful stress test results.

${ }^{19}$ This assumption could be a reason why some of the small banks, who might focus on prime customers, at least in some sectors, underperform in the tests, but the opposite could also be true (including the case that the outcome for some banks could be even worse in reality, but is not captured).
} 
Figure 4. Czech Republic: Potential Impact of Pillar 2 Capital Charges for Name Concentration

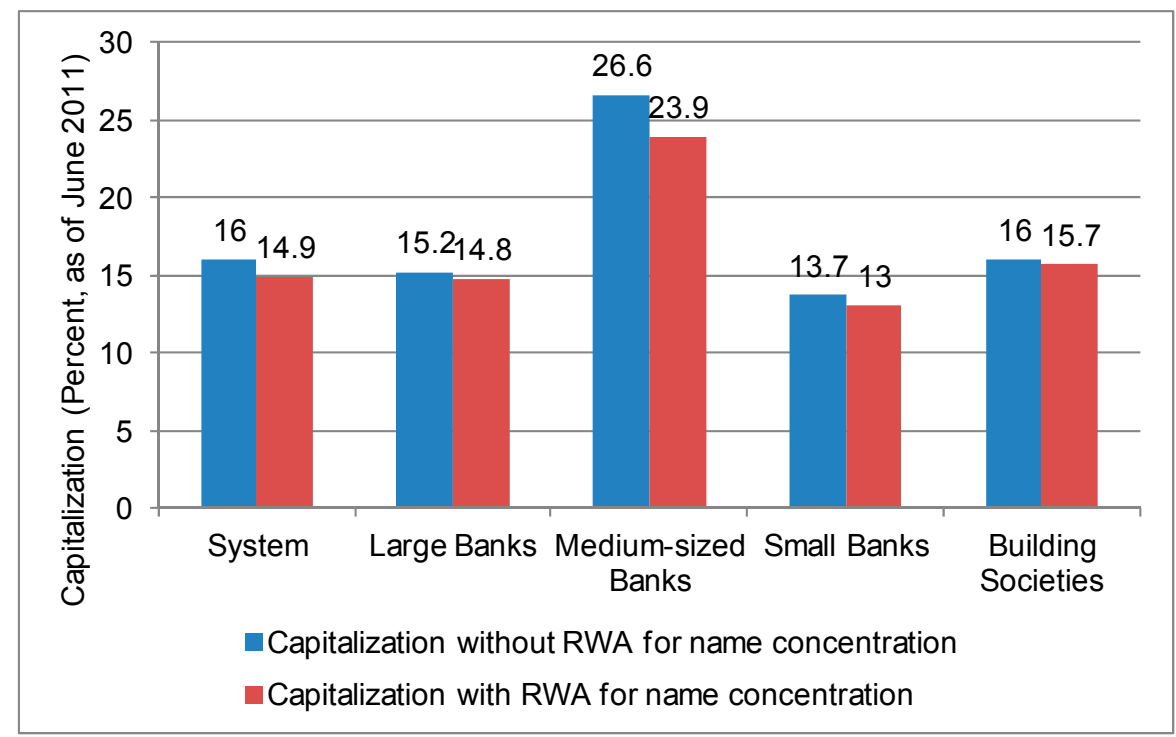

Source: IMF staff based on supervisory data.

\section{Credit Risk and Market Risk}

27. All credit risk parameters (PDs, LGDs, exposures at default (EADs)) were stressed based on satellite models, while market risk stress was directly derived from the scenarios. The projection of the credit risk parameters was based on a well-established CNB framework, used as a benchmark for the BU tests, while the TD IMF framework used international evidence to project the key credit risk parameters. In terms of market risk, banks' were assessed against foreign exchange (FX) risks, interest rate risk, and trading related income, including peripheral exposure (see Appendix II for further information). In the latter context, haircuts were applied to all exposure independent on the accounting treatment, taking account of the limited exposure overall.

\section{Income}

\section{Pre-impairment income was projected based on a combination of satellite} models and expert judgment. In case of the BU/TD CNB approach, the most important elements of income were treated separately, while the TD IMF attempted at forecasting the aggregate change of income (see Appendix II for further information).

\section{Banks were somewhat more optimistic in terms of their forecasts of pre-} impairment income, which largely made up by interest income. While there are good reasons to assume that lending margins could increase in case of an increase of interest rate, as a substantial part of deposits are demand deposits which are priced at close to zero, there will be foregone interest (from defaulting contracts) and above certain levels risk-adjusted 
pricing will influence the likelihood to repay as such, especially for weaker clients. Another key factor is the maturity structure of assets and liabilities, and the portion of fixed and variable interest rates. The BU test simulated that banks' capital would drop by about 10-15 percent under severe stress, compared to 50 percent in the case of the TD approaches.

30. The TD IMF framework explicitly captured the increase of funding costs conditional on banks' capitalization. The calibration has been done for a sample of Western European banks, and has been applied in other FSAPs (Table AIII.1). ${ }^{20}$ In this FSAP, accounting for the favorable funding structure of Czech banks, it has been assumed that banks can pass on most of the increase in the initial years, and slightly lesser so in the outer years (reflecting potential structural changes). ${ }^{21}$

\section{Risk-Weighted Assets}

31. The trajectories for banks' RWAs for credit risk under stress were simulated conditional on their Basel II approaches. ${ }^{22}$ Banks' RWAs for market risk and operational risk were assumed to remain largely constant. ${ }^{23}$ For the BU and TD CNB tests, the RWAs for market and operational risks have been assumed to remain constant. For the TD IMF tests, market risk RWAs were projected to grow proportionally with the GDP trajectories (i.e., to remain similar) while RWAs for operational risk were left unchanged. Banks' RWAs for other risks (which are very limited) were also left unchanged in both cases. As outlined above, Pillar 2 RWAs could be an integral part of the test in the future.

\section{The RWA trajectories projected by banks in the BU test were less conservative} than those projected by the TD models under more severe stress. The reason for that needs to be explored further, but could be related to the fact that banks assumed that the most risky counterparts default first, which reduces the RWAs of the remaining portfolio. The TD approaches led to similar levels of RWAs, but with the same time lag as for the single risk parameters.

\section{Dividend payout and behavioral adjustments}

\footnotetext{
${ }^{20}$ The framework seeks to link capitalization, measured in terms of implied PDs (for the bank as such), directly to levels of funding costs.

${ }^{21}$ Specifically, it has been assumed that the funding costs of banks increase by 25 percent in 2012 for those banks with an initial capitalization less than 12 percent, and that 75 percent of the increase in funding costs is passed on to customers in 2013, and 50 percent in the outer years (all figures relative to 2011). In some FSAPs, it has been assumed that banks cannot pass on any increase of funding costs to customers.

${ }^{22}$ RWAs for credit risk make up 86.5 percent of the total RWAs.

${ }^{23}$ On the system level, RWAs for credit risk make up 86.5 percent of the total RWAs, operational risk 11 percent, market risk 2.4 percent and other Pillar 1 risks account for 0.1 percent of total RWAs.
} 


\section{Dividend payout was oriented on past experience and banks' capitalization}

buffers. For all approaches, it was assumed that banks would abstain from paying dividends in case of negative income and/or if they are below the regulatory minimum capitalization. For the BU tests, banks were otherwise free to choose the level of dividend payout, and it appears that banks' chose the payout ratios in line business conditions. In case of the TD CNB approach, banks were assumed to pay out dividends so that capitalization after the dividend payout is equal to the initial level. ${ }^{24}$ For the IMF TD approach, it was assumed that banks with low capital buffers (i.e., capital buffers less 2.5 ppts above the regulatory minimum of 8 percent) would retain all profits while banks would pay out a portion (50 percent) similar to the long-term average (60 percent) otherwise. ${ }^{25}$ The remaining portion of net income was assumed to be retained. It was also assumed that banks would not raise any capital during the forecast period.

\section{Banks were assumed not to change their portfolio allocation during the}

projection period. Specifically, it was assumed that banks would not change their asset allocation to reduce RWAs; for example, by deleveraging substantially in terms of lending and replacing the exposure by securities. For the BU tests, banks were given some room to adjust their new business, which was expected to reflect experience in terms of lending standards during the last business cycle.

\section{Hurdle rates and Basel III}

35. A hurdle rate of 8 percent of total capitalization was applied. Due to the high quality of capital in most Czech banks (Tier 1 capitalization makes up 92 percent of total capitalization), referring to total capitalization appeared meaningful, in line with previous CNB stress tests. However, given that international standards are focusing on Tier 1 (and especially core Tier 1) ratios, future tests could be based on these measures. The TD IMF tests took into account the hurdle rates in terms of Tier 1 and Core Tier 1, but the tests revealed higher potential capital needs in all scenarios (where applicable) for total capitalization (reflecting the high quality of capital).

36. The stress tests explicitly accounted for the introduction of Basel III, which will have comparably limited impact on Czech banks (Table 3). As such, the following

\footnotetext{
${ }^{24}$ As the payout is simulated to happen in the second quarter of each year when part of the outlook is still not yet known, capitalization can still improve or worsen ultimately. The procedure in the FSAP tests was the same as the one used for the past CNB FSRs.

${ }^{25}$ A slightly higher retention ratio compared to the long-term average was chosen to reflect the general uncertainty of macroeconomic conditions.
} 
changes ${ }^{26}$ were considered: (a) higher capital ratios over time in terms of Tier 1 and Core Tier 1 capitalization; ${ }^{27}$ (b) the phase-out of capital eligibility over time; (c) higher risk weights for specific asset classes. In addition to the increase in risk weights, which are very limited for Czech banks, the TD IMF model assumed that 10 percent of total and Tier $1 /$ Core Tier $1^{28}$ capital would become ineligible and phased-out according to the Basel III schedule (i.e., in the outer years of the test horizon), informed by the outcome of the last Quantitative Impact Study (QIS) published in December 2010 for Group 2 banks. This can be seen as a (very) conservative estimate and should be refined going on. Computations by the mission show that on aggregate, banks will not be challenged by the leverage ratios. ${ }^{29}$

\footnotetext{
${ }^{26}$ Pursuant to agreements published by the Basel Committee on Banking Supervision (BCBS) in September and December 2010. See http://www.bis.org/press/p100912.htm

${ }^{27}$ As Czech banks do not use hybrid elements, both ratios are highly similar.

${ }^{28}$ Such capital elements include deferred tax assets, minority interests that exceed the permissible limit, deductions due to shortfall of provisions and deductions due to investments in financial institutions.

${ }^{29}$ The CNB comes to the same conclusion in the 2010/11 FSR (Box 7).
} 


\section{Table 3. Czech Republic: Overview of the Basel III Minimum Capital Requirements}

\begin{tabular}{|c|c|c|c|c|c|c|c|c|c|}
\hline \multicolumn{10}{|c|}{$\begin{array}{l}\text { Annex 2: Phase-in arrangements (shading indicates transition periods) } \\
\qquad \text { (all dates are as of } 1 \text { January) }\end{array}$} \\
\hline & 2011 & 2012 & 2013 & 2014 & 2015 & 2016 & 2017 & 2018 & $\begin{array}{l}\text { As of } \\
1 \text { January } \\
2019\end{array}$ \\
\hline Leverage Ratio & \multicolumn{2}{|c|}{ Supervisory monitoring } & \multicolumn{4}{|c|}{$\begin{array}{l}\text { Parallel inn } \\
\text { 1 Jan } 2013-1 \text { Jan } 2017 \\
\text { Disclosure tars } 1 \text { Jon } 2015\end{array}$} & & $\begin{array}{l}\text { Migration to } \\
\text { Pillar } 1\end{array}$ & \\
\hline Minimum Common Equity Capital Ratio & & & $3.5 \%$ & $4.0 \%$ & $4.5 \%$ & $4.5 \%$ & $4.5 \%$ & $4.5 \%$ & $4.5 \%$ \\
\hline Capial Conservation Buffer & & & & & & $0.625 \%$ & $1.25 \%$ & $1875 \%$ & $2.50 \%$ \\
\hline $\begin{array}{l}\text { Minimum common equity plus capital } \\
\text { conservaton buffer }\end{array}$ & & & $3.5 \%$ & $4.0 \%$ & $4.5 \%$ & $5.125 \%$ & $5.75 \%$ & $6375 \%$ & $7.0 \%$ \\
\hline $\begin{array}{l}\text { Phase-in of deductions from CET } 1 \\
\text { (including amounts exceeding the Imit for } \\
\text { DTAs, MSRs and financials ) }\end{array}$ & & & & $20 \%$ & $40 \%$ & $60 \%$ & $80 \%$ & $100 \%$ & $100 \%$ \\
\hline Minimum Tier 1 Capital & & & $4.5 \%$ & $5.5 \%$ & $6.0 \%$ & $6.0 \%$ & $6.0 \%$ & $6.0 \%$ & $6.0 \%$ \\
\hline Minimum Total Capital & & & $8.0 \%$ & $8.0 \%$ & $8.0 \%$ & $8.0 \%$ & $8.0 \%$ & $8.0 \%$ & $8.0 \%$ \\
\hline $\begin{array}{l}\text { Minimum Total Capital plus conservation } \\
\text { buffer }\end{array}$ & & & $8.0 \%$ & $8.0 \%$ & $8.0 \%$ & $8.625 \%$ & $9.25 \%$ & $9875 \%$ & $10.5 \%$ \\
\hline $\begin{array}{l}\text { Capial instruments that no longer qualify, } \\
\text { as non-core Tier } 1 \text { capital or Tier } 2 \text { capital }\end{array}$ & & & \multicolumn{7}{|c|}{ Phased out over 10 year horizon beginning 2013} \\
\hline Liquidity coverage ratio & $\begin{array}{l}\text { Observation } \\
\text { period } \\
\text { begins }\end{array}$ & & & & $\begin{array}{l}\text { Introduce } \\
\text { minmum } \\
\text { standard }\end{array}$ & & & & \\
\hline Net stable funding ratio & & $\begin{array}{l}\text { Coservation } \\
\text { period } \\
\text { begirs }\end{array}$ & & & & & & $\begin{array}{l}\text { Irtroduoe } \\
\text { minimum } \\
\text { standard }\end{array}$ & \\
\hline
\end{tabular}

Source: Basel Committee on Banking Supervision (BCBS 2010).

\section{Outcome of the Solvency Tests}

\section{On a standalone basis (i.e., excluding contagion from parents), the Czech} banking system is resilient against substantial shocks (Figure 5). Measured against current and future supervisory standards (Basel III, Table 3), Czech banks are, with some exceptions (mainly among the smaller banks), sufficiently capitalized to withstand stress scenarios. The favorable income position, along with high current capital buffers, enhances the resilience of the system.

\section{The severe DD scenario would bring the system close to the regulatory minimum}

(Figure 6). Under this scenario, the small banks are hit hardest, together with the building societies, but also some of the largest banks experience a noteworthy drop in the capitalization levels (Figure 7, left hand panel). ${ }^{30}$ Although the moderate DD and the slow growth scenario constitute substantial stress scenarios, the system does not experience a significant drop of capitalization, and many banks remain profitable under these stress levels.

\footnotetext{
${ }^{30}$ To incentivize small banks to reduce name concentration, the authorities could consider introducing a Pillar 2 charge as proposed by Schmieder, Puhr and Hasan (2011).
} 
Figure 5. Czech Republic: Outcome of Solvency Stress Tests for the Czech Banking System
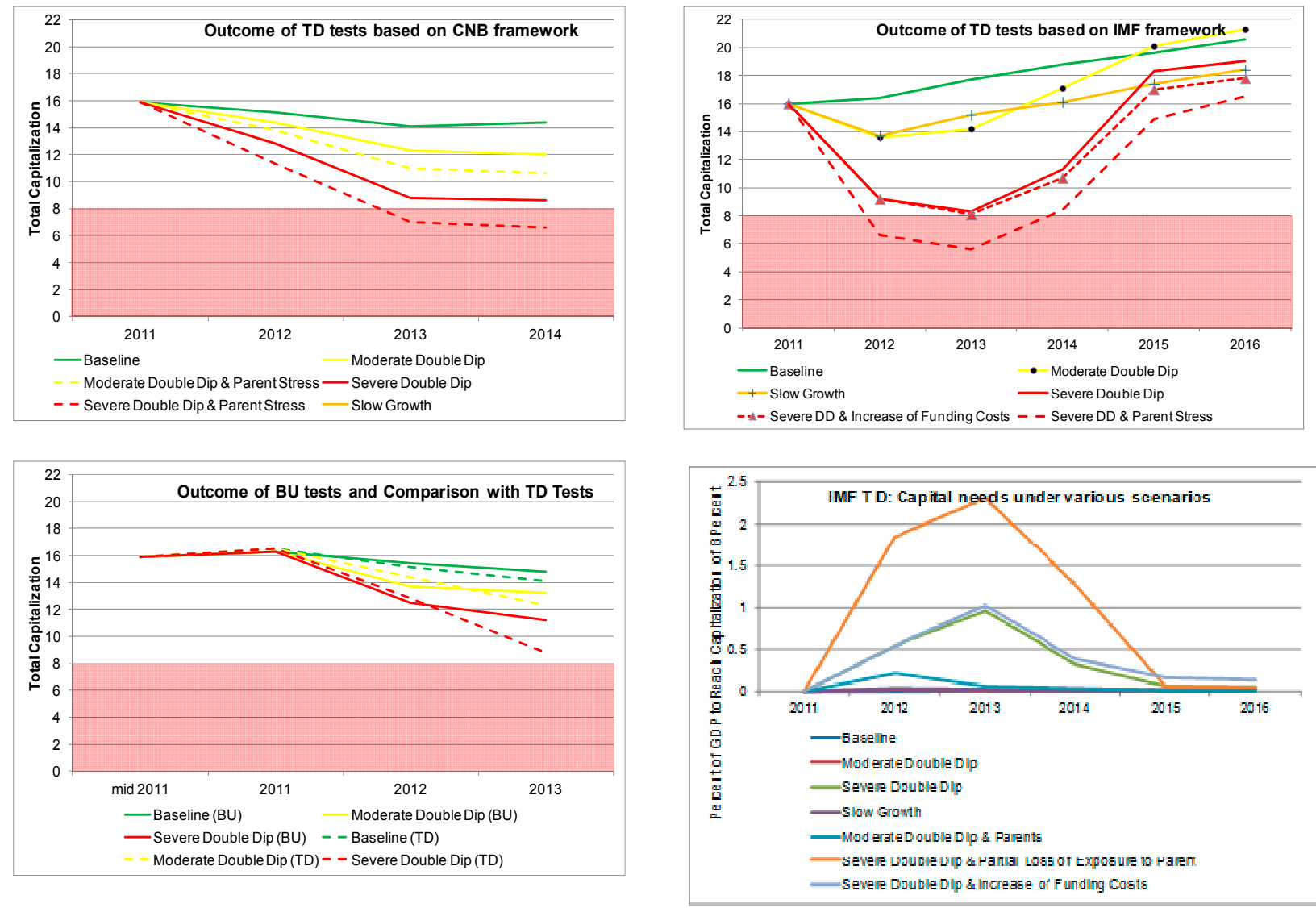

Source: Computations by largest banks based on banks' own data (BU test); CNB computations (TD CNB) and IMF staff computations (TD IMF) based on supervisory.

\section{Their high level of income allows banks to (re)build buffers within a comparably}

short period of time. As banks with capitalization levels less than 10.5 percent (i.e., those with capital conservation buffers less than $2.5 \mathrm{ppts}$ ) were assumed to fully retain positive net income (which is mainly relevant for the severe DD scenario during the recovery period), banks are able to rebuild capital buffers once stress vanishes, including through a reduction in RWAs, which happens at the same time. The latter explains part of the slower recovery of small banks after the severe DD shock, who do not benefit from decreasing RWAs from lower risk (as they are under the Standardized Approach), and their income buffers are also less sizeable as for large banks (Figure 6).

\section{Banks can absorb a reduction of their lending margins, including under severe}

stress. As displayed in Figure 5 (top right hand panel), it has been found that banks can digest higher funding costs, which have been simulated to affect banks conditional on their capitalization position in the previous year. A reduction in credit margins could results from 
contagion effects in the context of stress at the parent level, ${ }^{31}$ the latter one being likely to occur while facing a major recession scenario, as well as structural changes, (Figure 5, upper right hand side).

Figure 6. Czech Republic: Distribution of the Outcome of Solvency Stress Tests (Severe DD, without contagion risk)
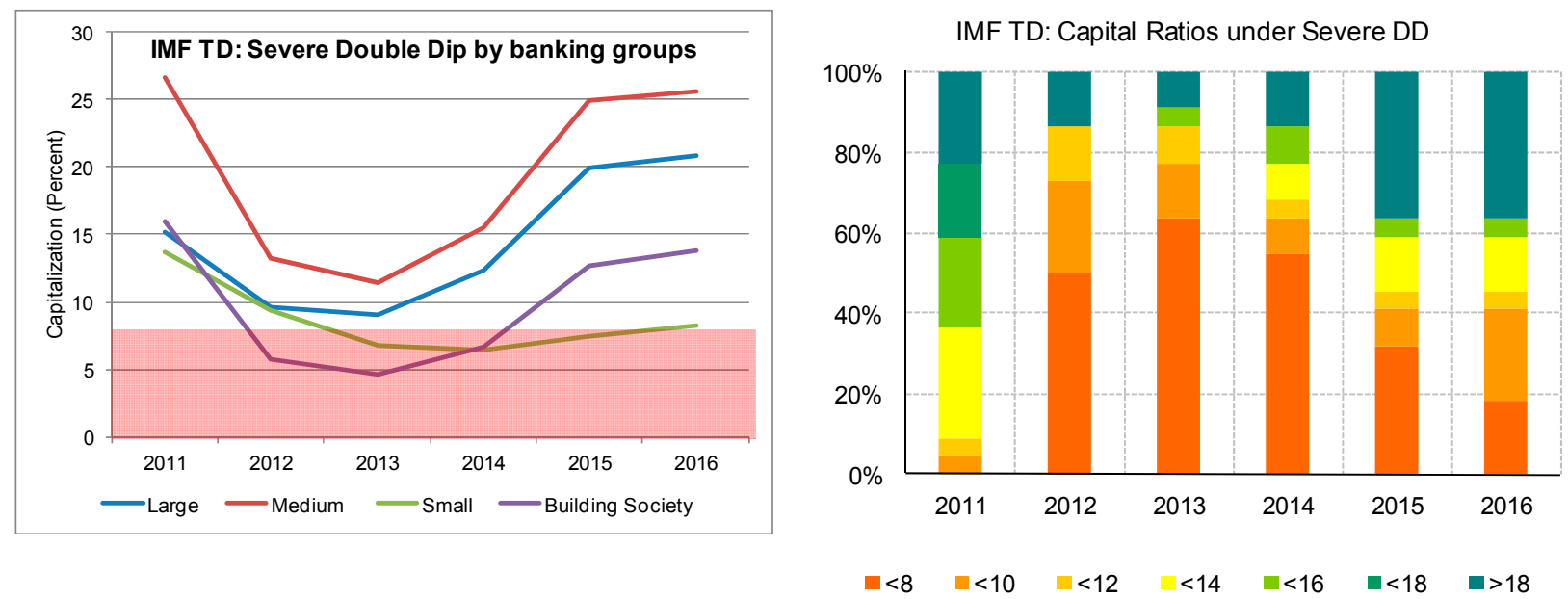

Source: IMF staff computations based on supervisory data.

\section{Direct contagion from stress at the parent level of the large Czech banks could} be material, and would challenge the Czech banking system. To capture a potential loss from exposure to their parent, a partial loss of exposure has been simulated (equal to 40 percent of the gross exposure), ${ }^{32}$ which was assumed to happen in 2012. As shown in the upper panels in Figure 6, the system would become slightly undercapitalized under the severe DD scenario (both for the TD CNB model and the TD IMF model), due to the simultaneous occurrence of substantial credit losses, reduced pre-impairment income and (only) limited deleveraging assumed for this scenario. Under moderate stress, the system would be able to absorb a loss of parent exposure (Figure 5, left hand panel). ${ }^{33}$ Recapitalization needs in such a scenario could require injections of up to 2 percent of GDP (Figure 6).

42. The resilience of the system differs across types of banks (Figure 6). While the purpose of the stress tests was explicitly not geared towards single banks, the results by

\footnotetext{
${ }^{31}$ If parent banks would become under severe stress, negative news could also impact their Czech subsidiaries, which could, in turn, increase their deposit rates to avoid a drain on their deposit funding base.

${ }^{32}$ The gross exposure includes loans as well as other positions vis-à-vis parent, especially through derivatives and the trading book, and is therefore a conservative estimate.

${ }^{33}$ The loss of parent exposure under moderate DD conditions for the TD IMF, which is not shown in Figure 6, would render similar results (in terms of magnitude of shock) as for the TD CNB model. In 2012, capitalization would be at 11.5 percent, and in 2013 at 12.3 .
} 
banking group (Figure 6, left hand panel) show that parts of the system are less resilient against potential stress. In terms of bank groups, it is the small banks and building societies that appear most vulnerable to shocks. Apart from somehow lower initial capitalization levels (for the small banks), it is their thinner income buffers that make smaller banks and building societies more vulnerable. As a caveat, it should be noted that the IRB credit risk parameters have been applied to small banks to compute potential loan losses (due to nonavailability of own estimates), which could result in over or underestimation of stress. It is also important to note that smaller banks use the StA, and thereby recover slower from stress than IRB banks. Figure 6 (right hand panel) shows the percentage of banks within different capitalization level. In 2013 and 2014, for example, more than half of the banks, but substantially less than half of the assets in the banking system (as the majority of the banks below 8 percent are smaller ones) would be below 8 percent under the severe DD scenario.

43. The outcome of the stress test is consistent across different methodologies. As displayed in Figure 5, the outcome of the BU is consistent with the outcome of the TD tests: the BU and TD CNB test find similar trajectories for banks' capitalization (panel in the middle, left hand side), and are in line with the TD IMF test in terms of the magnitude of the shock. The difference between the former two methods and the IMF framework is that capitalization is computed to drop with some time lag in case of the TD CNB model, as projected by the satellite model. In the TD IMF model, satellite models based on international evidence have been used, which simulate "point-in-time" (PIT) changes of the main risk parameters, that is, simulate the immediate materialization of stress.

\section{Name concentration could worsen the outcome of the severe DD scenario for}

some banks. A standalone sensitivity analysis reveals that the failure of the largest single nonbank exposure (on a borrower unit level) would result in losses equal to 9 percent of capital, ${ }^{34}$ or 1.4 ppts in terms of capitalization. For the largest $2(3 ; 10)$ exposures the loss would be equal to $2.1(2.7 ; 5)$ ppts of total capitalization. ${ }^{35}$ As indicated by the computation of potential RWAs for name concentration, name concentration is relatively limited in most banks, in line with international evidence for the same size of banks, but higher in some banks with a specific mandate and among the smaller banks. Pillar 2 charges could be an element to incentivize banks to reduce name concentration, unless this is justified by a special mandate (public banks), that is, a good reason to exempt specific banks.

\section{Banks' behavior in terms of credit growth would alter the outcome of the tests.}

Under the severe DD scenario, some deleveraging is foreseen. This assumption would help banks to withstand shocks and keep the system above 8 percent in 2013. In particular, if

\footnotetext{
34 This computation assumes an LGD of 45 percent.

35 The outcome is in line with the computations published in the CNB's Financial Stability Report (FSR) 2010/11 (Figure IV.40).
} 
banks were to deleverage by 10 percent (year-on-year), ${ }^{36}$ the system would, all else equal, be in a position to mitigate stress, including both in 2012 and 2013. Deleveraging would have feedback effects, but given the profitability of the system, deleveraging at some banks could be compensated, at least to some degree, by higher credit growth in other banks, so the overall impact of 10 percent deleveraging levels might be limited. ${ }^{37}$

\section{Banks can improve their capitalization ratios if they retain sizeable portions of}

their income. As revealed above, up to moderate stress levels banks can build sizeable capital buffers within a short period of time. Under the severe DD conditions, banks' behavior in terms of dividend payout would not matter during the stress years $(2012,2013)$, but matters in terms of how fast buffers can be rebuild.

\section{LIQUIDITY STRESS TESTS}

\section{A. Method and Scenarios}

\section{The liquidity tests focused on bank-run type stress scenarios assessing the} counterbalancing capabilities of banks. Two tests were conducted, run by banks (BU tests) and based on supervisory data (TD CNB) as of end June 2011. The BU stress tests involved the same sample of nine banks as for the solvency tests. The scenarios used were more severe than the ones previously run by the CNB (such as in the 2010/11 FSR), which were explicitly captured in the CNB FSR tests. However, due to the severity of the FSAP liquidity shocks, second round effects (which have been found to be rather limited in the previous CNB test) are meant to be implicitly captured. The analysis also sheds some light on risks arising from maturity mismatch and upcoming Basel III changes. The analyses are summarized in Appendix IV.

48. Two scenarios were simulated, a moderate one and a severe one (Table 4); the severe scenario simulated more adverse conditions than the ones faced by severely hit banks after the Lehman collapse. The customer deposit run-off rates for the moderate scenario are equal to the minimum ratios used for the Basel III Liquidity Coverage Ratio (LCR). For the wholesale deposits, the TD analyses were complemented by sensitivity analysis simulating a full loss of banks' (limited) wholesale funding. As a third element of stress on the liability side, it was assumed that banks need to generate additional funding for off-balance sheet exposure equal to up to 40 percent of that exposure. To counterbalance the outflow of funding, fire sales of liquid assets were simulated. Under severe stress, only cash and sovereign bonds were assumed to remain liquid, and government bonds can be sold at a

\footnotetext{
${ }^{36}$ This would imply substantial adjustment in cumulative terms, for two years of 19 percent, for example (10 percent in the first year and nine percent in the second year; in the latter case, it would be ten percent on 90 percent of the initial EAD).
} 
sizeable discount of 20 percent, which is (very) conservative, as government securities are central bank eligible, which would generate additional funding for banks. In both scenarios, it was assumed that the liquid assets are all unencumbered, in line with evidence.

Table 4. Czech Republic: Scenarios Used for Liquidity Tests

\begin{tabular}{|c|c|c|}
\hline Element & Moderate Stress & Severe Stress \\
\hline \multicolumn{3}{|c|}{ Loss of Funding \& additional funding needs } \\
\hline $\begin{array}{l}\text { Outflow of customer } \\
\text { deposits }\end{array}$ & $\begin{array}{c}\text { Demand: } 10 \\
\text { Term: } 5\end{array}$ & $\begin{array}{l}\text { Demand: } 20 \\
\text { Term: } 10\end{array}$ \\
\hline $\begin{array}{l}\text { Other deposits and } \\
\text { wholesale funding }\end{array}$ & 20 & 40 \\
\hline $\begin{array}{l}\text { Contingent Liabilities } \\
\text { drawn }\end{array}$ & 20 & 40 \\
\hline \multicolumn{3}{|c|}{ Inflow of Funds (from fire sales) } \\
\hline $\begin{array}{l}\text { Assets that remain } \\
\text { liquid }\end{array}$ & $\begin{array}{l}\text { Cash } \\
\text { Government Bonds } \\
\text { Other marketable securities }\end{array}$ & $\begin{array}{l}\text { Cash } \\
\text { Government Bonds }\end{array}$ \\
\hline Haircuts & $\begin{array}{l}\text { Cash: } 0 \\
\text { Government Bonds: } 10 \\
\text { Other marketable securities: } 20\end{array}$ & $\begin{array}{l}\text { Cash } \\
\text { Government Bonds: } 20\end{array}$ \\
\hline
\end{tabular}

Source: CNB and IMF staff

\section{Ample liquidity puts the vast majority of banks into a position to withstand} substantial stress (Figure 7). In addition to funding their business based on domestic deposits in local currency, banks hold about 20 percent of their assets in domestic government bonds, allowing them to generate liquidity if needed. TD tests also show that a full loss of wholesale funding and stress at the parent level, which results in extending the loans to their parents up to the regulatory maximum, does not materially change the outcome of the severe liquidity scenario, but should nevertheless be subject of close monitoring, as on the solvency side.

50. The results of the TD tests are broadly consistent with the BU tests, leaving most banks with considerable buffers. Specific banks have been found to be more vulnerable to liquidity shocks, especially among the medium-sized banks, and some action could be considered to contain potential risks ${ }^{38}$ (Figure 7, right hand panel). The banks that have been found to be most vulnerable (most of which can still be labeled resilient relative to banks in other systems) are those with higher loan-to-deposit ratios and/or potential funding needs for off-balance sheet items. The building societies have been found to be resilient against the shocks, but due to their maturity mismatch and the lowest liquid asset buffers complementary measures are needed. ${ }^{39}$ However, as all building societies are part of groups, they could be

\footnotetext{
${ }^{38}$ See the Financial Sector Stability Assessment (FSSA).

${ }^{39}$ See also the CNB's FSR 2010/11 on this subject.
} 
backstopped in case of stress. The reason for the BU test results being somehow less favorable results from differences in data (granularity), and can be used to refine the data used for the TD test and interpretation of its results.

Figure 7. Czech Republic: Outcome of Liquidity Stress Tests for the Czech Banking System
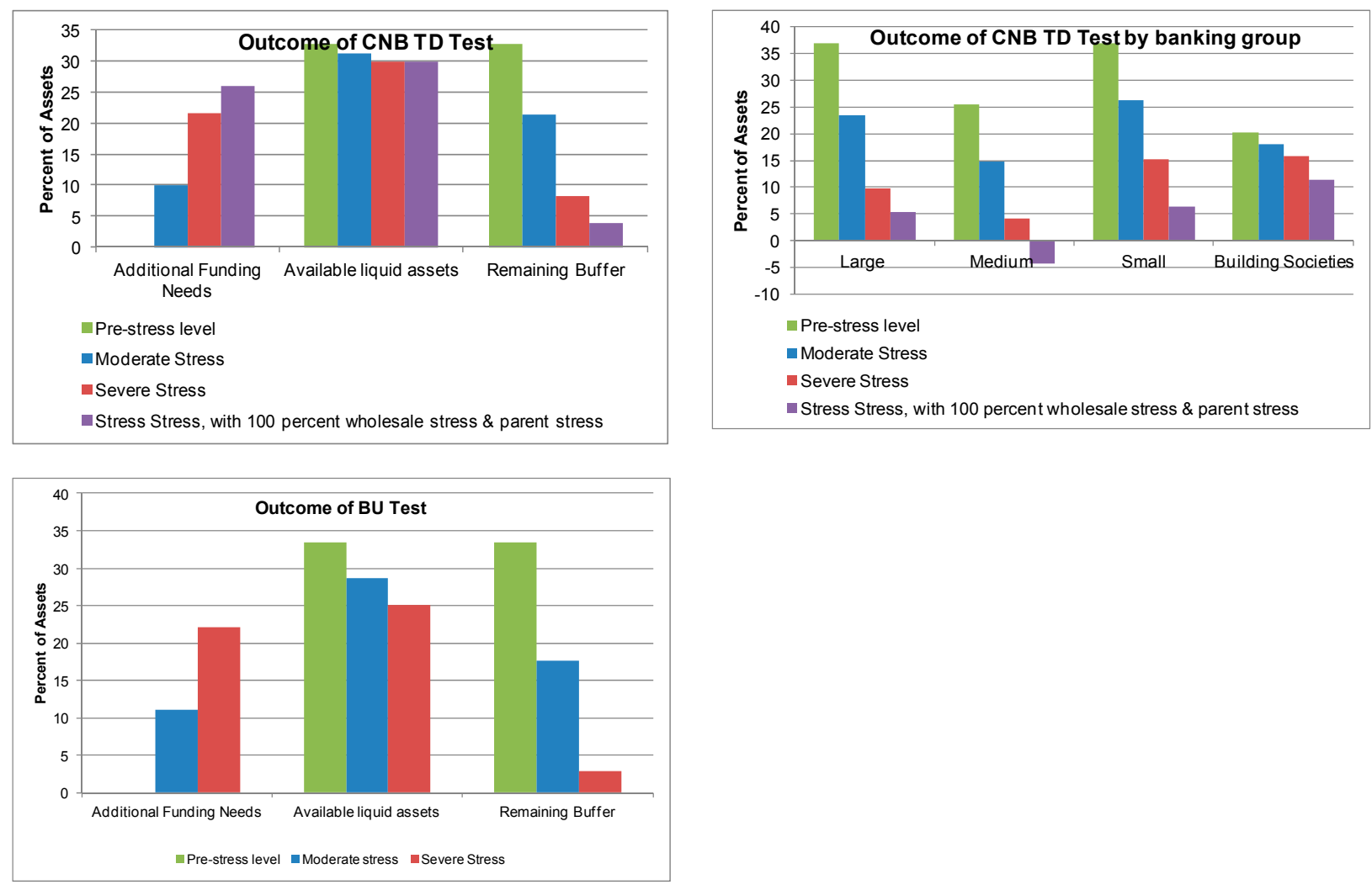

Source: CNB and IMF staff computations based on bank data and supervisory data.

51. Banks' maturity mismatch appears limited, with some exceptions. While the FSAP tests did not include specific tests to assess maturity mismatch, a proxy ("structured liquidity ratio") computed by the CNB for Net Stable Funding Ratio (NSFR) reveals a system-wide level above 110 percent and indicates that banks' maturity mismatch is manageable. Higher levels of maturity mismatch applies for the building societies (as also found in the FSR), which should be subject to close scrutiny. In the latter case, fully-fledged cash flow analysis could be used to monitor the liquidity position of banks. ${ }^{40} \mathrm{~A}$ proxy computed for the LCR (a "short-term liquidity ratio") confirms the above banks-run type scenarios in that banks appear robust against a sudden outflow of funding.

\footnotetext{
${ }^{40}$ Forthcoming work by Schmieder and others.
} 


\section{STRESS TESTS FOR NONBANKS}

\section{A. Insurance and Pension Sector}

\section{The insurance and pension sectors have not been subject to separate stress tests} during the FSAP. In previous integrated stress tests (i.e., originating from the same scenarios as the bank stress tests) carried out by the CNB, the insurance sector has been found to be resilient against substantial stress. While the tests cover a wide range of potential risks, they are limited to one year, whereby some of the risk might be hidden. The mission proposes to extend the time horizon and extend the tests on the liability side (see below). The pension sector, which has been found to be more vulnerable to shocks, should be subject to similar, extended tests as the insurance sector.

\section{B. Credit Unions}

\section{Credit unions were subject to the same stress scenarios as applied to banks} based on a simplified method. To do so, the average risk-return characteristics of the Czech credit unions were used (as reported in the CNB FSR), and stress was applied using rules of thumb proposed by Hardy and Schmieder (forthcoming). The main drivers projected by the framework were the evolution of pre-impairment profit, credit losses and credit growth, allowing for deleveraging under substantial stress. The RWAs were simulated as foreseen by the StA, with the outcome shown in Figure 8.

\section{The test revealed that credit unions are considerably more vulnerable to shocks} than banks, in line with the findings in the CNB FSR. For 50 percent of the credit unions, the moderate double dip scenario would bring their capitalization down towards the regulatory minimum (Tier 1 capitalization of less than 8 percent). Under a slow growth scenario the weakest 50 percent are projected to run short of capital after 2-4 years. A severe double dip scenario is devastating for most of the credit unions. 
Figure 8. Czech Republic: Simplified Stress Test for an Average Credit Union

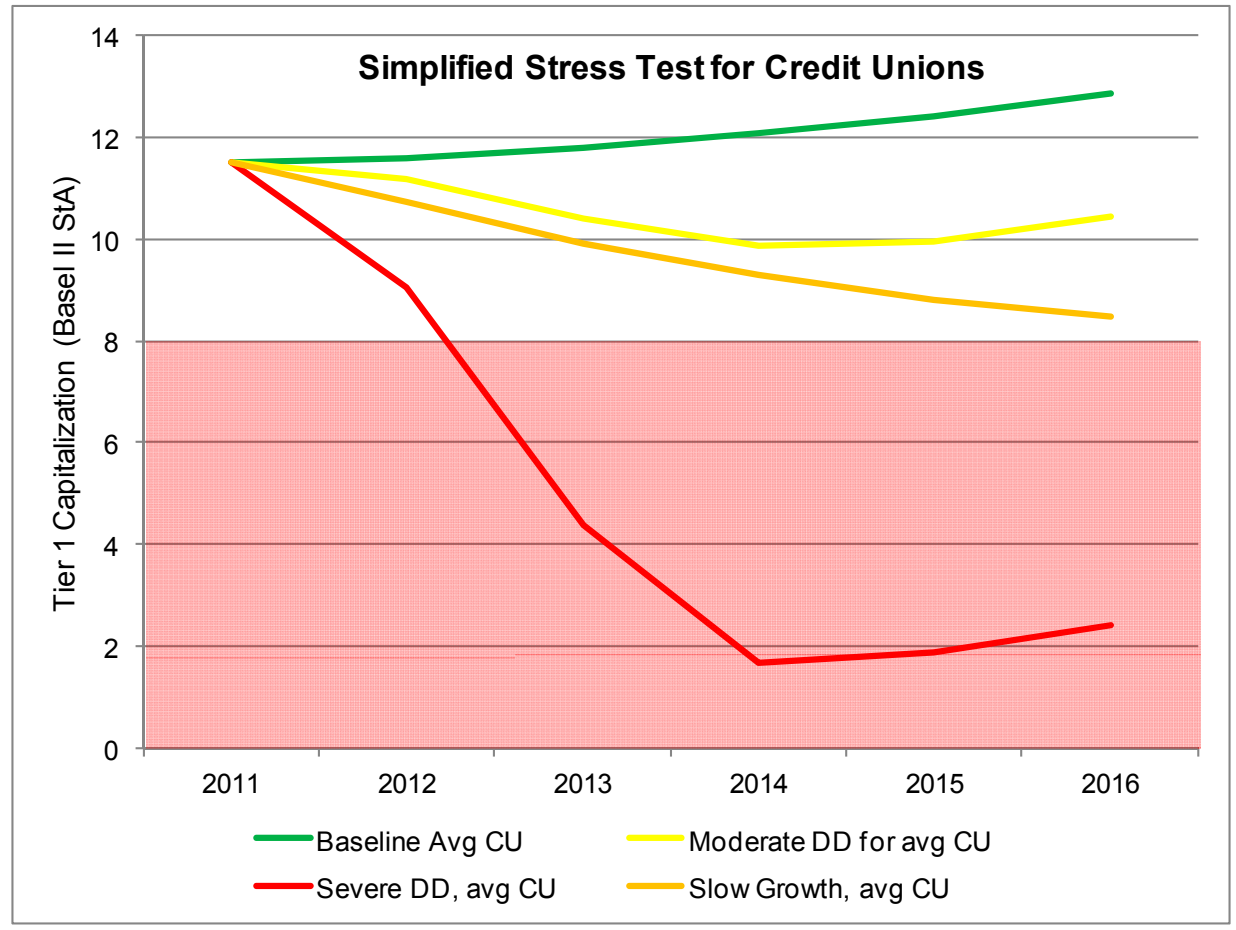

Source: Staff computations for average credit union.

\section{CONCLUSION AND RECOMMENDATIONS}

\section{Given the uncertain outlook for the European economy, the Czech banking} system's resilience could be tested going forward. Policies should focus on contagion risks and the weak end of the banking. In terms of contagion risk, supervisory policies should limit Czech banks overall solvency risks on the one hand but provide cross-border banking groups with reasonable room for maneuver to move capital and liquidity where it is most needed on the other (see also the FSSA and the technical note on macroprudential policies for further information). The weak ends of the system identified by the tests (and previous CNB tests) should be dealt with, which could be informed by countercyclical buffers and Pillar 2 charges, and thereby into account residual risks such as name concentration.

\section{The CNB's well-designed ${ }^{41}$ stress testing framework could be further}

strengthened. The framework could be extended to explicitly simulate the group-wide impact of stress. In this way, the framework would allow measuring the relative strength of the Czech banks in a group context, and could be used for monitoring purposes as well as a basis for macroprudential policies. The CNB could also consider refining the evolution of

\footnotetext{
${ }^{41}$ The CNB's framework is one of the very existing few frameworks that runs validation exercises of previous stress tests, for example. See Seidler and Geršl (2010).
} 
funding costs, income projections as such, and macrofinancial linkages more generally, which is an ongoing task around the world. Linking the liquidity tests to the scenarios used for the solvency tests, which is currently being developed, would also further strengthen the stress testing framework, as would tests assessing maturity mismatch through fully-fledged cash flow tests. ${ }^{42}$

57. Stress tests for the nonbank sector should also be upgraded further. For the insurance sector, long-term tests would be desirable, assessing firms' vulnerabilities vis-à-vis the (current) low interest environment. ${ }^{43}$ Likewise, the authorities should continuously monitor insurers' sensitivity to interest rate risks on both sides of the balance sheet and refine the tests on the liability side more generally. The stress tests for the pension sector could be aligned with the insurance sector.

\footnotetext{
${ }^{42}$ See forthcoming work by Schmieder and others, for example.

${ }^{43}$ Similar analysis have been carried out and published by the German authorities (BaFin, Bundesbank) for their insurance sector, for example.
} 


\section{REFERENCES}

Basel Committee on Banking Supervision (BCBS), 2006, “Basel II: International Convergence of Capital Measurement and Capital Standards: A Revised Framework Comprehensive Version," June (available at http://www.bis.org/publ/bcbs128.htm).

Basel Committee on Banking Supervision (BCBS), 2010a, "Basel III: A Global Regulatory Framework for More Resilient Banks and Banking System," December.

Basel Committee on Banking Supervision (BCBS), 2010b, "Results of the Comprehensive Quantitative Impact Study," December.

Basel Committee on Banking Supervision (BCBS), 2010c, "Basel III: International Framework for Liquidity Risk Measurement, Standards and Monitoring," December.

Cerutti, Eugenio, Anna Ilyina, Yulia Makarova and Christian Schmieder, 2010, Bankers Without Borders? Implications of Ring-Fencing for European Cross-Border Banks, IMF WP no. 10/247, http://www.imf.org/external/pubs/cat/longres.cfm?sk=24335.0.

CNB, 2010, Financial Stability Review 2010/11, November.

Hardy, Daniel, and Christian Schmieder, "Rules of Thumb for Solvency Stress Tests with a global case study," forthcoming IMF Working Paper (Washington: International Monetary Fund).

Seidler, Jakub, and Adam Geršl, 2010, Stress-tests Verificationt, Financial Stability Report 2009/2010, Czech National Bank, 2010, pp. 92-101.

Schmieder, Christian, Hesse, Heiko, Neudorfer, Benjamin, Puhr, Claus, and Stefan W. Schmitz, forthcoming, "Next Generation Balance Sheet Stress Testing - Liquidity Module,” IMF Working Paper (Washington: International Monetary Fund).

Schmieder, Christian, Puhr, Claus, and Maher K. Hasan, 2011, "Next Generation Balance Sheet Stress Testing," IMF Working Paper No. 11/83 (Washington: International Monetary Fund). 
APPENDIX I. STRESS TeSt MATRIX: SOLVENCY RISK AND SCENARIOS

\begin{tabular}{|c|c|c|}
\hline $\begin{array}{l}\text { Nature/Source } \\
\text { of Main Risks }\end{array}$ & $\begin{array}{l}\text { Likelihood of Severe Realization } \\
\text { of Risk in the Next } 1-3 \text { Years }\end{array}$ & $\begin{array}{c}\text { Expected Impact on Financial Stability if } \\
\text { Risk is Realized }\end{array}$ \\
\hline $\begin{array}{l}\text { A double dip } \\
\text { recession }\end{array}$ & $\begin{array}{l}\text { Medium } \\
\text { - Despite the global recovery after } \\
\text { the culmination of the financial } \\
\text { crisis in 2008/09, the sovereign } \\
\text { debt crisis has increased } \\
\text { uncertainties substantially. The } \\
\text { vulnerabilities of the Western } \\
\text { European sovereigns (but also the } \\
\text { U.S. and Japan), together with a } \\
\text { cooling down of major emerging } \\
\text { economies could develop into a } \\
\text { global DD recession with adverse } \\
\text { macrofinancial feedback loops for } \\
\text { the Czech Republic. } \\
\text { - The macroeconomic and financial } \\
\text { conditions are particularly weak in } \\
\text { many European economies. This } \\
\text { could result in a full blown global } \\
\text { recession (severe DD) or a lighter } \\
\text { dip based on regional stress, which } \\
\text { could still be felt (moderate double } \\
\text { dip), the former one with } \\
\text { noteworthy impact for the Czech } \\
\text { Republic and the latter one with } \\
\text { some impact. }\end{array}$ & $\begin{array}{l}\text { Medium/High } \\
\text { - Depending on the severity of the shock, } \\
\text { the Czech economy could be hit harder } \\
\text { and for a longer time than in } 2008 \text { or at } \\
\text { least moderately, with slowed growth, } \\
\text { more unfavorable export markets, and a } \\
\text { drop in asset prices. The impact of } \\
\text { shocks could be amplified by } \\
\text { countercyclical fiscal policies. } \\
\text { - The shocks could be further amplified by } \\
\text { a reversal of capital flows. The pertinent } \\
\text { impact depends on the severity of the } \\
\text { macroeconomic shock and whether there } \\
\text { is flight-to-quality. } \\
\text { - Macroeconomic shocks would have } \\
\text { negative effects on banks' asset quality } \\
\text { (i.e., result in credit losses), first through } \\
\text { spillovers and then domestically if stress } \\
\text { persisted, reduce banks' pre-impairment } \\
\text { income; both effects could lead to a } \\
\text { substantial drop of capitalization or a } \\
\text { gradual reduction, respectively. The } \\
\text { concentration of banks' lending activities } \\
\text { in commercial real estate and mortgages } \\
\text { is particularly sensitive to a severe } \\
\text { macroeconomic shock, as is corporate } \\
\text { exposure. } \\
\text { - Specific banks could also face some } \\
\text { challenges in terms of funding resulting } \\
\text { from concerns on solvency of their parent } \\
\text { banks, in addition to being to a certain } \\
\text { degree challenged by Basel III effects. } \\
\text { Lending margins could shrink as a } \\
\text { consequence of fiercer competition for } \\
\text { deposits, and reduce banks' first line of } \\
\text { defense against losses. }\end{array}$ \\
\hline $\begin{array}{l}\text { Slow growth } \\
\text { scenario }\end{array}$ & $\begin{array}{c}\text { High } \\
\text { - Ongoing uncertainty in global } \\
\text { financial markets could increase }\end{array}$ & $\begin{array}{l}\text { Medium } \\
\text { - Although the Czech Republic might } \\
\text { initially not be directly hit, its growth will }\end{array}$ \\
\hline
\end{tabular}




\begin{tabular}{|c|c|c|}
\hline $\begin{array}{l}\text { Nature/Source } \\
\text { of Main Risks }\end{array}$ & $\begin{array}{l}\text { Likelihood of Severe Realization } \\
\text { of Risk in the Next } 1-3 \text { Years }\end{array}$ & $\begin{array}{c}\text { Expected Impact on Financial Stability if } \\
\text { Risk is Realized }\end{array}$ \\
\hline & $\begin{array}{l}\text { global risk aversion and reduce } \\
\text { capital flows (to banks and } \\
\text { corporates) away from countries } \\
\text { like the Czech Republic, which } \\
\text { have been perceived, to some } \\
\text { degree, as safe heaven. } \\
\text { - Unless the potential shock } \\
\text { translates into a full blown } \\
\text { recession (see above), a (global) } \\
\text { tendency towards flight-to-quality } \\
\text { fuelled by persistent uncertainties } \\
\text { in Europe resulting from the } \\
\text { sovereign debt crisis could lead to } \\
\text { a period of stagnation, i.e. a period } \\
\text { of Japan-like growth conditions } \\
\text { (albeit not necessarily with } \\
\text { deflationary tendencies). }\end{array}$ & $\begin{array}{l}\text { be under pressure of the external } \\
\text { demand slowdown of its main trade } \\
\text { partners, especially Germany. } \\
\text { - Exchange rates against major currencies } \\
\text { and financial markets could face higher } \\
\text { volatility, and amplify the stress } \\
\text { conditions. } \\
\text { - In addition to the moderate to medium } \\
\text { level stress impact on banks' asset } \\
\text { quality and pre-impairment income, some } \\
\text { of the banks (especially those without } \\
\text { strong parent banks) could face higher } \\
\text { funding costs, resulting from competition } \\
\text { for deposits, and Basel III effects could } \\
\text { amplify the situation to some degree. }\end{array}$ \\
\hline $\begin{array}{l}\text { Failure of a } \\
\text { foreign parent } \\
\text { bank }\end{array}$ & $\begin{array}{l}\text { Medium } \\
\text { - In case of a materialization of stress } \\
\text { in the Euro Area as a result of the } \\
\text { sovereign debt crisis, parent banks } \\
\text { could be negatively affected, which } \\
\text { would have at least some } \\
\text { repercussions on the Czech } \\
\text { subsidiaries } \\
\text { - Recent stress test results by the } \\
\text { EBA (to reach Core Tier } 1 \text { ratios of } \\
9 \text { percent) could amplify this stress } \\
\text { conditions at the parent level. }\end{array}$ & $\begin{array}{l}\text { High } \\
\text { - The failure of a parent of a relatively large } \\
\text { Czech bank would have systemic } \\
\text { repercussions. } \\
\text { - Some strains at parent banks could be } \\
\text { felt in the Czech Republic, with parents } \\
\text { upstreaming capital and/or liquidity and } \\
\text { thus limiting the action space of the } \\
\text { subsidiaries. Reputational risk could put } \\
\text { pressure on liquidity and funding costs. In } \\
\text { principle, subsidiaries could also be } \\
\text { pressured to deleverage, which could } \\
\text { have some feedback effects on the } \\
\text { economy unless other banks increase } \\
\text { their market share at the same time. }\end{array}$ \\
\hline
\end{tabular}

Source: IMF staff. 


\section{Appendix Table 1. Czech Republic: Evolution of Macroeconomic Variables under Different Scenarios}

\begin{tabular}{|c|c|c|c|c|c|c|}
\hline \multicolumn{7}{|c|}{ Macroeconomic Scenario } \\
\hline Baseline & 2011 & 2012 & 2013 & 2014 & 2015 & 2016 \\
\hline Real GDP Growth (YoY) & 2.0 & 1.8 & 2.5 & 2.7 & 3.2 & 3.2 \\
\hline CZK/EUR & 24.4 & 23.9 & 23.4 & 23.3 & 23.6 & 23.6 \\
\hline CPI Inflation (YoY) & 1.8 & 1.9 & 2.1 & 2.0 & 2.1 & 1.8 \\
\hline ILO Unemployment Rate & 7.1 & 6.9 & 6.6 & 7.0 & 7.3 & 8.0 \\
\hline Nom. Wage Growth (YoY) & 3.3 & 5.8 & 5.9 & 4.7 & 4.6 & 4.5 \\
\hline Euro Zone Real GDP \% pa y-o-y & 2.7 & 2.1 & 3.0 & 3.4 & 3.5 & 3.1 \\
\hline Interest Rates & & & & & & \\
\hline ank Rate \% pa & 1.7 & 1.9 & 2.7 & 3.3 & 3.2 & 3.3 \\
\hline Euro 1-Year Interbank Rate \% pa & 1.3 & 1.2 & 1.6 & 2.4 & 2.8 & 3.1 \\
\hline Euro 3-Month Interbank Rate \% pa & 1.4 & 1.1 & 1.3 & 2.1 & 2.7 & 3.0 \\
\hline Moderate Double Dip & 2011 & 2012 & 2013 & 2014 & 2015 & 2016 \\
\hline Real GDP Growth (YoY) & 2.0 & -0.4 & -0.7 & 1.6 & 3.0 & 3.2 \\
\hline CZK/EUR & 24.4 & 23.0 & 22.9 & 23.3 & 23.3 & 23.5 \\
\hline CPI Inflation (Y & 1.8 & 1.4 & 0.2 & 0.4 & 1.0 & 1.0 \\
\hline ILO Unemployment Rate & 7.0 & 7.1 & 7.8 & 8.6 & 9.6 & 10.7 \\
\hline Nom. Wage Growth (YoY) & 3.4 & 6.4 & 4.6 & 1.2 & 0.8 & 2.1 \\
\hline Euro Zone Real GDP \% pa y-o-y & 2.7 & 2.1 & 3.0 & 3.4 & 3.5 & 3.1 \\
\hline Interest Rates & & & & & & \\
\hline 1 -Year Ir & 1.7 & 0.5 & 1.1 & 2.0 & 1.6 & 1.6 \\
\hline ank Rate \% pa & 1.3 & 1.2 & 1.6 & 2.4 & 2.8 & 3.1 \\
\hline Euro 3-Month Interbank Rate \% pa & 1.4 & 1.1 & 1.3 & 2.1 & 2.7 & 3.0 \\
\hline Severe Double Dip & 2011 & 2012 & 2013 & 2014 & 2015 & 2016 \\
\hline Real GDP Growth (YoY) & 1.6 & -3.3 & -5.1 & -0.9 & 3.5 & 3.2 \\
\hline CZK/EUR & 24.4 & 26.9 & 28.1 & 27.6 & 27.2 & 26.5 \\
\hline CPI Inflation (YoY) & 1.9 & 3.2 & 2.5 & 1.4 & 1.7 & 1.4 \\
\hline ILO Unemployment Rate & 7.1 & 7.8 & 9.4 & 11.4 & 12.2 & 13.7 \\
\hline Nom. Wage Growth (YoY) & 3.1 & 2.0 & 3.5 & 4.4 & 4.3 & 3.9 \\
\hline Euro Zone Real GDP \% pa y-o-y & 2.5 & -1.8 & -2.1 & 2.1 & 4.9 & 5.6 \\
\hline Interest Rates & & & & & & \\
\hline 1-Year Interbank $\mathrm{F}$ & 1.8 & 3.1 & 2.4 & 3.0 & 3.5 & 3.6 \\
\hline Euro 1-Year Interbank Rate \% pa & 1.3 & 1.2 & 1.6 & 2.4 & 2.8 & 3.1 \\
\hline Euro 3-Month Interbank Rate \% pa & 1.4 & 1.1 & 1.3 & 2.1 & 2.7 & 3.0 \\
\hline Slow Growth & 2011 & 2012 & 2013 & 2014 & 2015 & 2016 \\
\hline Real GDP Growth (YoY) & 1.7 & -0.8 & 0.1 & 0.1 & 0.5 & 0.6 \\
\hline CZK/EUR & 24.4 & 25.9 & 25.9 & 25.8 & 25.6 & 25.4 \\
\hline CPI Inflation (YoY) & 1.8 & 1.8 & 1.4 & 1.2 & 1.6 & 1.2 \\
\hline ILO Unemployment Rate & 7.1 & 7.5 & 7.4 & 8.1 & 8.1 & 10.0 \\
\hline Nom. Wage Growth (YoY) & 3.1 & 2.2 & 2.5 & 3.8 & 4.5 & 4.1 \\
\hline Euro Zone Real GDP \% pa y-o-y & 2.6 & 0.2 & 1.4 & 2.1 & 2.5 & 2.5 \\
\hline Interest Rates & & & & & & \\
\hline 1 -Year Interbank Rate \% pa & 1.7 & 1.6 & 0.9 & 1.7 & 2.0 & 1.9 \\
\hline Euro 1-Year Interbank Rate \% pa & 1.3 & 1.2 & 1.6 & 2.4 & 2.8 & 3.1 \\
\hline Euro 3-Month Interbank Rate \% pa & 1.4 & 1.1 & 1.3 & 2.1 & 2.7 & 3.0 \\
\hline
\end{tabular}

Source: The CNB and IMF staff. 


\section{APPENDiX II. Projections OF THE Key Stress TeSt DRIVERS}

\section{A. Credit Risk}

58. The trajectories of the PDs were determined based on satellite models. For the CNB TD tests, separate models have been used for the corporate and household sector, developed by the CNB during recent years, using a nonlinear, Merton-based framework. ${ }^{44}$ The models include various macroeconomic input parameters commonly used to determine firms' and households' repayment capacities, and try to capture the lag with which the real sector is hit following a shock. Accordingly, the models produce PIT credit risk parameters under different scenarios at each point in time of the forecast horizon. For the BU tests, banks were given the flexibility to use their own models and to deviate from the CNB benchmark trajectories for the main Basel II asset classes (computed based on the CNB PD frameworks) with sufficient justifications, an option which was used by some banks (but the deviations from the benchmark were quite small). ${ }^{45}$ In the IMF framework, a technically straightforward but nonlinear satellite model based on the GDP trajectories (alone) was used, calibrated based on the universe of bank data around the world for the last 15 years around the world, thereby capturing various types of crisis and stress levels (using Hardy and Schmieder, forthcoming). The satellite model thereby implicitly captures economic and financial risk, ${ }^{46}$ as well as feedback effects, and has been calibrated with a view to be on the conservative end.

59. The trajectories of LGD have been established based on a combination of a satellite model and expert judgment (TD CNB) and through a link to PDs, respectively (TD IMF). For the CNB TD model and the BU tests, benchmark trajectories have been defined by the CNB, calibrated based on a simplified satellite model. For the IMF computations, an empirical link between PDs and LGDs has been used, using international evidence and account for downturn conditions. ${ }^{47}$

60. The EAD has been projected based on satellite models. For the CNB TD approach and the BU tests, credit growth projections (including off-balance sheet credit) have been established based on a combination of satellite models and expert judgment. For the IMF TD method, empirical evidence by Hardy and Schmieder has been applied, which foresees a

\footnotetext{
${ }^{44}$ Further information can be found on the CNB webpage in different working papers and FSRs.

${ }^{45}$ In future tests, banks might be given this option to run alternative scenarios, for example, to shed light on how much banks' expectations could alter the outcome of stress, which also applies to other relevant stress factors.

${ }^{46}$ Hence, both crises originating from macroeconomic stress and crises triggered within the financial sector (by asset bubbles, for example) were captured.

${ }^{47}$ See Schmieder, Puhr and Hasan (2011) for more information.
} 
linear relationship between macroeconomic conditions in terms of GDP growth and credit growth.

\section{B. Market Risk}

\section{Market risk was stressed using the projections of key market risk parameters} under stress, and measuring the impact on income. The main risks for the Czech banking system, for which market risks account for only 2.4 percent of total RWAs, are interest rate risk and FX risk. As banks hedge at least part of these two risks, the impact is limited unless there is a highly adverse scenario. For both TD tests, market risk was captured by means of (a) the changes of the yield curves of local currency and the euro as well as (b) the FX rate of the CZK against other relevant currencies (most importantly the euro) were the main inputs for the stress tests (Appendix Table I). Changes in FX rates were applied to the net open positions, assuming that the net open positions remain as they are as of June 2011). For the TD IMF tests interest rate risk was applied proportionally to the impact of 200 basis point shock on income (again in static terms), while for TD CNB, the impact was estimated using the average duration of the bond portfolios of individual banks, taking into account potential hedges against interest rate risk; banks used their internal models to compute the actual impact of the specific scenarios (as of their today's portfolios) for the BU test, yielding similar results in broad terms.

\section{Haircuts were applied to banks' exposure to the GIIPS countries, accounting for}

the level of stress. Conceptually, the change in the market value of the GIIPS assets is assumed to result from credit risk only (i.e., that there is no additional impact resulting from a change in the yield curve), and stress is applied subsequently to the assets both to the trading and the banking book. ${ }^{48}$ For the TD test and under baseline conditions, a haircut of 25 percent was assumed for Greece, 15 percent for Portugal and Ireland, and 10 percent for Spain and Italy. Under the moderate dip scenario and the slow growth scenario, the haircuts were doubled, and under severe stress it was assumed that stress is equal to four times the baseline haircut (i.e., that there is full loss of the exposure to Greece). For the BU tests, the haircut in case of the baseline scenario was computed based on changes in the market value during the second half of the year till November 15. For the other stress scenarios, additional haircuts similar to the absolute changes used for the TD tests were used. In sum, the assumptions were chosen with a view to be on the conservative end, at least for severe stress. Overall, the exposure constitutes about 0.7 percent of banks total assets, so the impact of any haircut will remain limited. It should also be noted that stress was applied to the entire credit exposure to the GIIPS, that is, including corporate and bank exposure.

\footnotetext{
${ }^{48}$ For the holding in the trading book and fair value option assets, a decrease in fair value is simulated, while for the banking book (AFS and HTM portfolios) the stress scenarios simulates the impact of impairments in the profit and loss account.
} 


\section{Pre-impairment (pre-tax) operating income}

63. Pre-impairment operating income was projected based on satellite models and expert judgment. For the TD CNB and BU test, five subcategories of pre-impairment income have been considered, aiming at capturing differences in the sensitivities of the elements, while the TD IMF approach sought to project the evolution of the aggregate preimpairment income, taking into account that banks are following a traditional bank model (i.e., are not heavily engaged in trading, which makes income more volatile, especially under severe stress). ${ }^{49}$ All components were meant to be projected conditional on the scenario, that is, the evolution of relevant risk factors. For the TD CNB and BU approach, the following five components of pre-impairment operating income have been taken into account, with net interest income accounting for 69 percent of total income and net commission and fee income 23 percent (Figure AII.1):

- Interest Income;

- Interest Expenses;

- Net fees and commission income and other income;

- Trading income (other than interest and FX risk and GIIPS risk captured separately); and

- Administrative expenses.

Figure 9. Czech Republic: Decomposition of Czech Banks' Operating Income

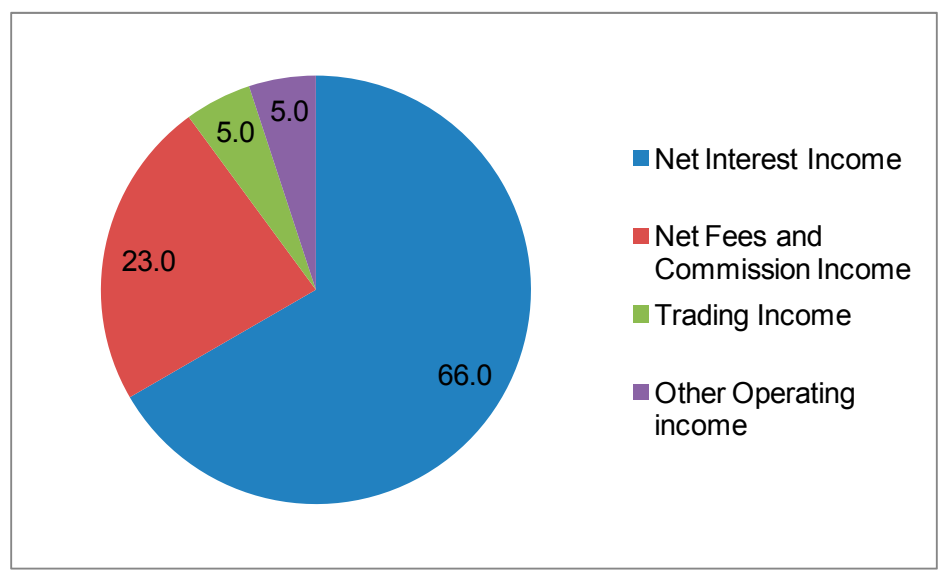

Source: Supervisory Data

64. In the BU tests, banks were explicitly asked to forecast interest income using their own models. The idea was to shed light on the magnitude of potential differences between banks' own views (which are, in terms of income, often on more benign as those of

${ }^{49}$ See Hardy and Schmieder (forthcoming) in this context. 
the authorities) and the trajectories used for the TD tests. Banks were asked to take into account the evolution of interest rates and volume of credit portfolios, as well as credit losses and hedges via interest rate derivatives (e.g., Interest Rate Swaps, etc.). Banks were asked to justify any increase of net interest income under stress. For the interest rate expenses, in addition to using their models to account for changes in interest rate levels, banks were given a rule of thumb how interest expenses evolve conditional on their capitalization levels under stress, accounting for existing uncertainties in the markets (leading to increased competition for deposits; and customer differentiating to some degree between banks in terms of their solvency position). ${ }^{50}$

\section{For the other components of pre-impairment operating profit banks were asked}

to apply expert judgment. As for interest income, banks were not expected to increase net commission and fee income under stress, unless there is valid justification to do so. For the BU test, trading income was simulated to drop by 10 percent in the baseline (compared to the average from 2005-2010), by 50 percent in the moderate DD scenario and by 90 percent under severe stress, but as it makes up only 6 percent of total income the impact is limited. For the same reason, the CNB TD tests assumed that trading income remains constant at the level observed in the first half of 2011 (at 5 percent), which is similar to its average $5-6$ percent portion of total income during the last 5 years.

\footnotetext{
${ }^{50}$ The rule foresaw that banks' interest expenses would increase by 15 basis points for each drop of 0.5 ppts below 12 percent, i.e., for a capitalization of 11 percent banks would increase their funding costs by 30 basis points compared a specific point in time with a time lag of 6 months, but only on the expense side. It was therefore assumed that banks cannot pass on the increase in funding costs, which is very conservative.
} 
Appendix Table II. Czech Republic: Comparison of the Trajectories of Key Risk Drivers by Method

\begin{tabular}{|c|c|c|c|c|c|c|}
\hline Baseline & 2011 & 2012 & 2013 & 2014 & 2015 & 2016 \\
\hline \multicolumn{7}{|c|}{ Credit Losses/1 } \\
\hline \multirow{3}{*}{$\begin{array}{l}\text { BU } \\
\text { TD CNB } \\
\text { TD IMF }\end{array}$} & 1.00 & 1.03 & 1.08 & & & \\
\hline & 1.00 & 1.14 & 1.20 & 1.06 & & \\
\hline & 1.00 & 1.05 & 0.99 & 0.94 & 0.94 & 0.89 \\
\hline \multicolumn{7}{|l|}{ EAD } \\
\hline \multirow{3}{*}{$\begin{array}{l}\text { BU } \\
\text { TD CNB } \\
\text { TD IMF }\end{array}$} & 1.00 & 1.04 & 1.10 & & & \\
\hline & 1.00 & 1.03 & 1.07 & 1.11 & & \\
\hline & 1.00 & 1.04 & 1.08 & 1.14 & 1.20 & 1.27 \\
\hline \multicolumn{7}{|c|}{ Pre-impairment Income } \\
\hline \multirow{3}{*}{$\begin{array}{l}\text { BU } \\
\text { TD CNB } \\
\text { TD IMF }\end{array}$} & 1.00 & 0.96 & 0.98 & & & \\
\hline & 1.00 & 0.93 & 1.01 & 1.07 & & \\
\hline & 1.00 & 0.98 & 1.03 & 1.04 & 1.05 & 1.07 \\
\hline \multicolumn{7}{|l|}{ RWAs } \\
\hline \multirow{3}{*}{$\begin{array}{l}\text { BU } \\
\text { TD CNB } \\
\text { TD IMF }\end{array}$} & 1.00 & 1.04 & 1.16 & & & \\
\hline & 1.00 & 0.99 & 1.13 & 1.25 & & \\
\hline & 1.00 & 1.07 & 1.10 & 1.14 & 1.19 & 1.24 \\
\hline Moderate DD & 2011 & 2012 & 2013 & 2014 & 2015 & 2016 \\
\hline \multicolumn{7}{|l|}{ Credit Losses/1 } \\
\hline \multirow{3}{*}{$\begin{array}{l}\mathrm{BU} \\
\text { TD CNB } \\
\text { TD IMF }\end{array}$} & 1.00 & 1.16 & 1.42 & & & \\
\hline & 1.00 & 1.80 & 2.09 & 1.77 & & \\
\hline & 1.00 & 1.39 & 1.41 & 1.02 & 0.78 & 0.75 \\
\hline \multicolumn{7}{|l|}{ EAD } \\
\hline \multirow{3}{*}{$\begin{array}{l}\text { BU } \\
\text { TD CNB } \\
\text { TD IMF }\end{array}$} & 1.00 & 1.04 & 1.10 & & & \\
\hline & 1.00 & 1.02 & 1.01 & 1.03 & & \\
\hline & 1.00 & 1.01 & 1.01 & 1.04 & 1.10 & 1.16 \\
\hline \multicolumn{7}{|c|}{ Pre-impairment Income } \\
\hline \multirow{3}{*}{$\begin{array}{l}\text { BU } \\
\text { TD CNB } \\
\text { TD IMF }\end{array}$} & 1.00 & 0.96 & 0.98 & & & \\
\hline & 1.00 & 0.68 & 0.63 & 0.69 & & \\
\hline & 1.00 & 0.85 & 0.83 & 0.97 & 1.06 & 1.07 \\
\hline \multicolumn{7}{|l|}{ RWAs } \\
\hline \multirow{3}{*}{$\begin{array}{l}\text { BU } \\
\text { TD CNB } \\
\text { TD IMF }\end{array}$} & 1.00 & 1.07 & 1.10 & & & \\
\hline & 1.00 & 1.05 & 1.26 & 1.38 & & \\
\hline & 1.00 & 1.18 & 1.17 & 1.04 & 0.96 & 0.98 \\
\hline Severe DD & 2011 & 2012 & 2013 & 2014 & 2015 & 2016 \\
\hline \multicolumn{7}{|l|}{ Credit Losses/1 } \\
\hline \multirow{3}{*}{$\begin{array}{l}\text { BU } \\
\text { TD CNB } \\
\text { TD IMF }\end{array}$} & 1.00 & 1.43 & 2.14 & & & \\
\hline & 1.00 & 2.92 & 3.38 & 2.35 & & \\
\hline & 1.00 & 2.26 & 2.76 & 1.66 & 0.68 & 0.73 \\
\hline \multicolumn{7}{|l|}{ EAD } \\
\hline \multirow{3}{*}{$\begin{array}{l}\text { BU } \\
\text { TD CNB } \\
\text { TD IMF }\end{array}$} & 1.00 & 1.00 & 0.95 & & & \\
\hline & 1.00 & 1.00 & 0.97 & 0.93 & & \\
\hline & 1.00 & 0.96 & 0.90 & 0.89 & 0.95 & 1.00 \\
\hline Pre-impairmen & come & & & & & \\
\hline$B U$ & 1.00 & 0.92 & 0.86 & & & \\
\hline TD CNB & 1.00 & 0.63 & 0.30 & 0.18 & & \\
\hline TD IMF & 1.00 & 0.67 & 0.55 & 0.82 & 1.09 & 1.07 \\
\hline RWAs & & & & & & \\
\hline $\mathrm{BU}$ & 1.00 & 1.07 & 1.08 & & & \\
\hline TD CNB & 1.00 & 1.14 & 1.49 & 1.53 & & \\
\hline TD IMF & 1.00 & 1.44 & 1.40 & 1.11 & 0.83 & 0.89 \\
\hline
\end{tabular}

Source: CNB and IMF staff.

1/ The figures are not directly comparable between BU/TD CNB and TD IMF as the former figures measure loss rate for customer credit and the latter for total exposure subject to credit risk. In addition to that, the BU/TD CNB models were calibrated based on quarterly data, which were annualized to be compared with the TD IMF figures. 


\section{APPENDIX III. STRESS TEST MATRIX FOR SOLVENCY}

\begin{tabular}{|c|c|c|c|}
\hline \multirow[t]{2}{*}{ Domain } & \multicolumn{3}{|c|}{ Assumptions } \\
\hline & $\begin{array}{l}\text { Bottom-Up by Banks } \\
\text { (if applicable) }\end{array}$ & $\begin{array}{l}\text { Top-Down by Authorities } \\
\text { (if applicable) }\end{array}$ & $\begin{array}{c}\text { Top-down by FSAP Team } \\
\text { (if applicable) }\end{array}$ \\
\hline Institutions included & - 9 & - All banks & - All Banks \\
\hline Market share & $\begin{array}{l}\text { - Percentage of total } \\
\text { sector assets: } 80\end{array}$ & $\begin{array}{l}\text { - Percentage of total } \\
\text { sector assets: } 100\end{array}$ & $\begin{array}{l}\text { - Percentage of total } \\
\text { sector assets: } 100\end{array}$ \\
\hline $\begin{array}{l}\text { Data and baseline } \\
\text { date }\end{array}$ & - Banks' own data & - Supervisory & - Supervisory \\
\hline Methodology & $\begin{array}{l}\text { - Combination of banks' } \\
\text { own models and pre- } \\
\text { defined benchmarks } \\
\text { (oriented on CNB } \\
\text { framework, agreed with } \\
\text { mission) }\end{array}$ & $\begin{array}{l}\text { - CNB stress testing } \\
\text { framework }\end{array}$ & $\begin{array}{l}\text { - IMF framework } \\
\text { (Schmieder, Puhr and } \\
\text { Hasan, 2011) }\end{array}$ \\
\hline Stress test horizon & - Consolidated & - Consolidated & - Consolidated \\
\hline Shocks & \multicolumn{3}{|c|}{$\begin{array}{l}\text { - } 2.5 \text { years (BU), } 3 \text { years (TD CNB); } 5 \text { years (TD IMF) } \\
\text { - Shocks based on GDP trajectories, other variables evolve conditional on GDP } \\
\text { (according to output of CNB's macro model) } \\
\text { - Double Dip ( } 1 \mathrm{StD} \text { and } 2.5 \mathrm{StD} \text { in historical terms), Slow Growth (cumulative } 5 \\
\text { year deviation equal to } 2 \mathrm{StD} \text {, only based on TD IMF framework) }\end{array}$} \\
\hline $\begin{array}{l}\text { Risks/factors } \\
\text { assessed }\end{array}$ & $\begin{array}{l}\text { - Comprehensive } \\
\text { coverage of solvency } \\
\text { risks (Credit, Market, } \\
\text { income risks, fixed } \\
\text { income holdings of } \\
\text { banks in peripheral } \\
\text { Europe, funding risk) }\end{array}$ & $\begin{array}{l}\text { - Comprehensive } \\
\text { coverage of solvency } \\
\text { risks (Credit, Market, } \\
\text { income risks, fixed } \\
\text { income holdings of } \\
\text { banks in peripheral } \\
\text { Europe, funding risk, } \\
\text { concentration risk) }\end{array}$ & $\begin{array}{l}\text { - Comprehensive } \\
\text { coverage of solvency } \\
\text { risks (Credit, Market, } \\
\text { income risks, fixed } \\
\text { income holdings of } \\
\text { banks in peripheral } \\
\text { Europe, funding risk, } \\
\text { concentration risk) }\end{array}$ \\
\hline $\begin{array}{l}\text { Calibration of risk } \\
\text { parameters }\end{array}$ & $\begin{array}{l}\text { - Credit losses, pre- } \\
\text { impairment income and } \\
\text { credit growth based on } \\
\text { satellite models, haircut } \\
\text { on GIIPS exposure and } \\
\text { funding risks based on } \\
\text { expert judgment } \\
\text { - PIT risk parameters for } \\
\text { credit risk parameters } \\
\text { based on banks' IRB } \\
\text { models, and proxies for } \\
\text { the other banks }\end{array}$ & $\begin{array}{l}\text { - Credit losses, pre- } \\
\text { impairment income and } \\
\text { credit growth based on } \\
\text { satellite models, haircut } \\
\text { on GIIPS exposure and } \\
\text { funding risks based on } \\
\text { expert judgment } \\
\text { - PIT risk parameters for } \\
\text { credit risk parameters } \\
\text { based on banks' IRB } \\
\text { models, and proxies for } \\
\text { the other banks }\end{array}$ & $\begin{array}{l}\text { - Credit losses, pre- } \\
\text { impairment income, } \\
\text { credit growth and } \\
\text { funding costs based on } \\
\text { satellite models; haircut } \\
\text { on GIIPS exposure and } \\
\text { funding risks based on } \\
\text { expert judgment } \\
\text { - PIT risk parameters for } \\
\text { credit risk parameters } \\
\text { based on banks' IRB } \\
\text { models and proxies for } \\
\text { the other banks; } \\
\text { - Asset correlations were } \\
\text { assumed to be fixed } \\
\text { (i.e., not to decrease } \\
\text { with increasing PDs, } \\
\text { LGDs), based on } \\
\text { Schmieder, Puhr and } \\
\text { Hasan (2011) }\end{array}$ \\
\hline Behavioral & - Credit growth projected & - Credit growth projected & - Credit growth projected \\
\hline
\end{tabular}




\begin{tabular}{|c|c|c|c|}
\hline \multirow[t]{2}{*}{ Domain } & \multicolumn{3}{|c|}{ Assumptions } \\
\hline & $\begin{array}{l}\text { Bottom-Up by Banks } \\
\text { (if applicable) }\end{array}$ & $\begin{array}{l}\text { Top-Down by Authorities } \\
\text { (if applicable) }\end{array}$ & $\begin{array}{c}\text { Top-down by FSAP Team } \\
\text { (if applicable) }\end{array}$ \\
\hline adjustments & $\begin{array}{l}\text { by satellite model, pre- } \\
\text { defined payout } \\
\text { depending on income } \\
\text { after stress/capital } \\
\text { buffer on banks' IRB } \\
\text { models }\end{array}$ & $\begin{array}{l}\text { by satellite model, pre- } \\
\text { defined payout } \\
\text { depending on income } \\
\text { after stress/capital } \\
\text { buffer }\end{array}$ & $\begin{array}{l}\text { by satellite model, } \\
\text { assumption that capital } \\
\text { constraint banks (i.e., } \\
\text { those with capital } \\
\text { conservation buffers } \\
\text { less than } 2.5 \text { ppts } \\
\text { would fully retain profit), } \\
\text { otherwise in line with } \\
\text { evidence for the Czech } \\
\text { Republic }\end{array}$ \\
\hline $\begin{array}{l}\text { Regulatory } \\
\text { standards }\end{array}$ & $\begin{array}{l}\text { - Hurdle rates based on } \\
\text { Basel II/III minimum for } \\
\text { Total Capital and Tier } 1 \\
\text { (Core Tier } 1 \text { is basically } \\
\text { in line with Tier } 1 \text { ) } \\
\text { - Basel II/III IRB rules }\end{array}$ & $\begin{array}{l}\text { - Hurdle rates based on } \\
\text { Basel II/III minimum for } \\
\text { Total Capital and Tier } 1 \\
\text { (Core Tier } 1 \text { is basically } \\
\text { in line with Tier } 1 \text { ) } \\
\text { - Basel II/III IRB rules, \& } \\
\text { StA }\end{array}$ & $\begin{array}{l}\text { - Hurdle rates based on } \\
\text { Basel II/III minimum for } \\
\text { Total Capital and Tier } 1 \\
\text { (Core Tier } 1 \text { is basically } \\
\text { in line with Tier } 1 \text { ) } \\
\text { - Basel II/III (quasi-) IRB } \\
\text { rules, \& StA }\end{array}$ \\
\hline Results & $\begin{array}{l}\text { - CAR/shortfall, system } \\
\text { wide. } \\
\text { - Pass or fail; percentage } \\
\text { of assets that fail. }\end{array}$ & $\begin{array}{l}\text { - CAR/shortfall, system } \\
\text { wide. } \\
\text { - Pass or fail; percentage } \\
\text { of assets that fail. }\end{array}$ & $\begin{array}{l}\text { - CAR/shortfall, system } \\
\text { wide. } \\
\text { - Pass or fail; percentage } \\
\text { of assets that fail. }\end{array}$ \\
\hline
\end{tabular}

Source: IMF staff

Figure 10. Czech Republic: Schematic Overview for the Calibration of Funding Costs

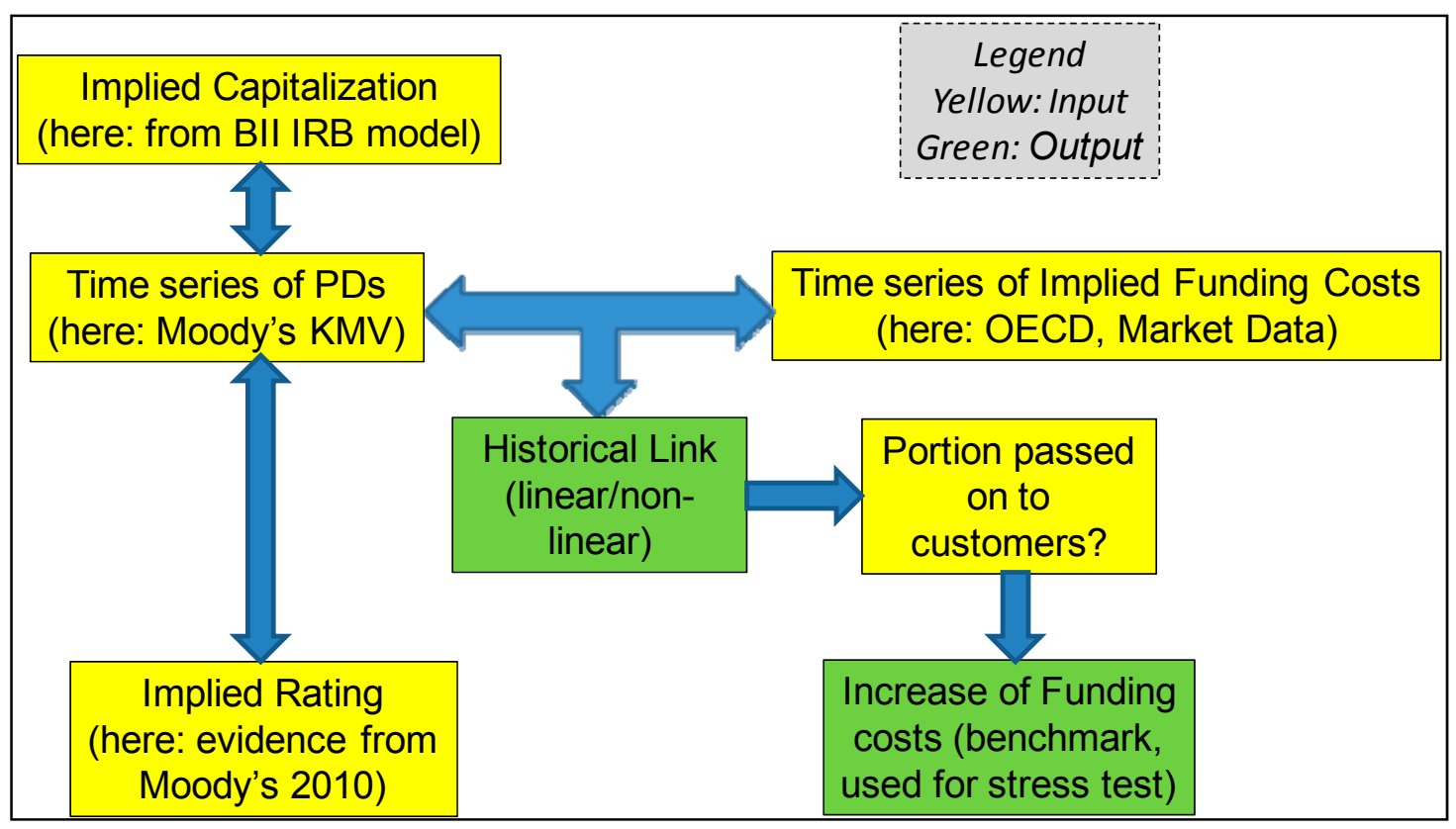


Appendix Table III. Czech Republic: Calibration of Funding Costs used for the FSAP

\begin{tabular}{|l|c|c|c|}
\hline $\begin{array}{l}\text { Rating } \\
\text { Scale } \\
\text { (Moody's) }\end{array}$ & One Year PDs & $\begin{array}{c}\text { Funding costs } \\
\text { (Spread above t- } \\
\text { bills, bps) }\end{array}$ & $\begin{array}{c}\text { Economic capital ratio } \\
\text { (Basel II (quasi-IRB) }\end{array}$ \\
\hline Aaa & $0.004 \%$ & 10.0 & $28.1 \%$ \\
Aa1 & $0.006 \%$ & 10.0 & $27.3 \%$ \\
Aa2 & $0.008 \%$ & 10.0 & $26.2 \%$ \\
Aa3 & $0.010 \%$ & 10.0 & $21.2 \%$ \\
A1 & $0.012 \%$ & 11.3 & $19.7 \%$ \\
A & $0.026 \%$ & 13.2 & $14.3 \%$ \\
A2 & $0.060 \%$ & 22.1 & $13.9 \%$ \\
Baa1 & $0.135 \%$ & 25.8 & $11.7 \%$ \\
Baa2 & $0.200 \%$ & 38.8 & $11.1 \%$ \\
Baa3 & $0.291 \%$ & 64.2 & $9.9 \%$ \\
Ba1 & $0.682 \%$ & 66.7 & $8.5 \%$ \\
Ba2 & $0.728 \%$ & 107.5 & $8.4 \%$ \\
Ba3 & $1.791 \%$ & 124.5 & $7.1 \%$ \\
B1 & $2.450 \%$ & 150.6 & $6.7 \%$ \\
B2 & $3.827 \%$ & 194.1 & $6.2 \%$ \\
B3 & $7.666 \%$ & 205.4 & $5.4 \%$ \\
Caa1 & $9.150 \%$ & 241.9 & $5.3 \%$ \\
Caa2 & $16.388 \%$ & 334.5 & $4.8 \%$ \\
Caa3 & $24.806 \%$ & 448.0 & $3.0 \%$ \\
Ca/C & $32.949 \%$ & 600.0 & $1.5 \%$ \\
\hline
\end{tabular}




\section{APPENDIX IV.STRESS TEST MATRIX FOR LIQUIDITY RISK}

\begin{tabular}{|c|c|c|c|}
\hline \multirow[t]{2}{*}{ Domain } & \multicolumn{3}{|c|}{ Assumptions } \\
\hline & Bottom-Up by Banks & Top-Down by Authorities & Top-down by FSAP Team \\
\hline Institutions included & - 9 & - All & \\
\hline Market share & - 80 & - 100 & \\
\hline $\begin{array}{l}\text { Data and baseline } \\
\text { date }\end{array}$ & - Banks' own data & - Supervisory data & \\
\hline Methodology & $\begin{array}{l}\text { Bank-run type test } \\
\text { based on two scenarios } \\
\text { (moderate and severe } \\
\text { bank-run, with } \\
\text { scenarios similar to } \\
\text { previous stress tests in } \\
\text { CNB, see technical } \\
\text { note for details); }\end{array}$ & $\begin{array}{l}\text { Bank-run type test, } \\
\text { based on two scenarios } \\
\text { (moderate and severe } \\
\text { bank-run, with } \\
\text { scenarios similar to } \\
\text { previous stress tests in } \\
\text { CNB, see technical } \\
\text { note for details); Basel } \\
\text { III ratio (LCR, NSFR) }\end{array}$ & $\begin{array}{c}\text { NA } \\
\text { (Robustness checks } \\
\text { based on publicly } \\
\text { available data) }\end{array}$ \\
\hline Risks & $\begin{array}{l}\text { - Funding liquidity \& } \\
\text { market liquidity }\end{array}$ & $\begin{array}{l}\text { - Funding liquidity \& } \\
\text { market liquidity, } \\
\text { maturity mismatch } \\
\text { (NSFR) }\end{array}$ & \\
\hline $\begin{array}{l}\text { Regulatory } \\
\text { standards }\end{array}$ & - NA & $\begin{array}{l}\text { - Proxy for Basel III ratios } \\
\text { (LCR, NSFR) }\end{array}$ & \\
\hline Results & $\begin{array}{l}\text { - Pass rate (Liquidity } \\
\text { Position relative to } \\
\text { Assets) }\end{array}$ & $\begin{array}{l}\text { - Pass rate (Liquidity } \\
\text { Position relative to } \\
\text { Assets) }\end{array}$ & \\
\hline
\end{tabular}

Source: IMF staff 